\title{
Apocynaceae s. str. do Parque Nacional da Serra da Canastra, Minas Gerais, Brasil ${ }^{1}$
}

\author{
Apocynaceae s. str. of the Serra da Canastra National Park, State of Minas Gerais, Brazil
}

\author{
Rosemeri Morokawa ${ }^{2,3}$, André Olmos Simões ${ }^{2}$ \& Luiza Sumiko Kinoshita ${ }^{2}$
}

\begin{abstract}
Resumo
Este trabalho apresenta o levantamento das espécies de Apocynaceae s. str. no Parque Nacional da Serra da Canastra, localizado no sudoeste de Minas Gerais. Foram encontradas 30 espécies, distribuídas em 13 gêneros. A subfamília Rauvolfioideae está representada por 11 espécies pertencentes a cinco gêneros: Aspidosperma, Condylocarpon, Hancornia, Himatanthus e Tabernaemontana, enquanto Apocynoideae está representada por 19 espécies distribuídas em oito gêneros: Forsteronia, Mandevilla, Mesechites, Odontadenia, Peltastes, Prestonia, Secondatia e Temnadenia. São apresentadas chaves analíticas para a identificação de gêneros e espécies, descrições, ilustrações e comentários sobre distribuição geográfica.
\end{abstract}

Palavras-chave: Apocynoideae, campo rupestre, florística, Rauvolfioideae.

\begin{abstract}
A species inventory for the Apocynaceae $s$. str. occurring in the Serra da Canastra National Park, located in southwestern Minas Gerais, is presented in this study. The floristic survey reported 30 species from 13 genera. Subfamily Rauvolfioideae is represented by 11 species belonging to five genera: Aspidosperma, Condylocarpon, Hancornia, Himatanthus and Tabernaemontana). Subfamily Apocynoideae is represented by 19 species belonging to eigth genera: Forsteronia, Mandevilla, Mesechites, Odontadenia, Peltastes, Prestonia, Secondatia and Temnadenia. Keys for the identification of the genera and species, descriptions, illustrations, and comments on geographical distribution of the species are presented.
\end{abstract}

Key words: Apocynoideae, campo rupestre, floristics, Rauvolfioideae.

\section{Introdução}

Apocynaceae $s$. l. é uma das maiores famílias de angiospermas. Apresenta 375 gêneros e 5000 espécies com distribuição pantropical e algumas espécies em regiões temperadas (Endress 2004). No Brasil, são registradas 759 espécies (Rapini et al. 2010), distribuídas em todos os domínios morfoclimáticos brasileiros. Apocynaceae $s$. $l$. pertence à ordem Gentianales e, recentemente, teve sua circunscrição ampliada com a inclusão de Asclepiadaceae. Essa delimitação é resultado de estudos em sistemática filogenética baseados em caracteres morfológicos e moleculares (Judd et al. 1994, Struwe et al. 1994, Sennblad \& Bremer 2002) e corrobora com a primeira circunscrição proposta para a família por Jussieu (1789). Atualmente, está subdividida em cinco subfamílias: Rauvolfioideae, Apocynoideae, Periplocoideae, Secamonoideae e Asclepiadoideae
(Endress \& Bruyns 2000), das quais Rauvolfioideae, Apocynoideae e Asclepiadoideae ocorrem no Brasil. A citação Apocynaceae s. str. refere-se apenas às subfamílias Rauvolfioideae e Apocynoideae.

O levantamento de Apocynaceae s. str. no Parque Nacional da Serra da Canastra (PNSC) está inserido no projeto Flora do Parque Nacional da Serra da Canastra e, somado ao estudo de Farinaccio \& Mello-Silva (2004) para a subfamília Asclepiadoideae, traz novas informações para o conhecimento da diversidade da família no PNSC.

O objetivo deste trabalho é catalogar e descrever a diversidade de Apocynaceae s. str. que, junto às demais famílias já estudadas, contribui para o conhecimento da flora do PNSC. Em adição, objetiva contribuir com o conhecimento da Flora de Minas Gerais, assim como dos campos rupestres e cerrados brasileiros.

\footnotetext{
Parte da dissertação de Mestrado da primeira autora.

${ }^{2}$ Universidade Estadual de Campinas, Inst. Biologia, Depto. Biologia Vegetal, C.P. 6109, 13083-970, Campinas, SP, Brasil

${ }^{3}$ Autora para correspondência: rmorokawa@gmail.com
} 


\section{Material e Métodos}

Área de estudo

O PNSC localiza-se na região sudoeste do estado de Minas Gerais, nos municípios de São Roque de Minas, Delfinópolis, Sacramento, Vargem Bonita, São João Batista do Glória e Capitólio, entre os meridianos de $46^{\circ} 15^{\prime}$ e $47^{\circ} 00^{\prime} \mathrm{W}$ e os paralelos de $20^{\circ} 00^{\prime}$ e $20^{\circ} 30^{\prime} \mathrm{S}$ (IBAMA 2005). A área do PNSC é de 200.000 ha, proposta pelo Decreto $\mathrm{n}^{\circ}$ 70.355, em 3 de abril de 1972. Deste total, somente 71.525 ha estão com a situação fundiária regularizada. No entanto, os outros 130.000 ha permanecem como propriedades particulares ou posses. Nesse trabalho, a área de estudo abrange a área da proposta original, ampliando a diversidade de ambientes e possivelmente a diversidade de espécies (Fig. 1).

As cotas altimétricas variam de 900 a 1.200 $\mathrm{m}$, atingindo a máxima de $1.496 \mathrm{~m}$ na Serra Brava. O clima regional é caracterizado pela sazonalidade com chuvas no verão e inverno seco. A temperatura média é de $21^{\circ} \mathrm{C}$ e a precipitação pluviométrica varia de 1.300 a $1.700 \mathrm{~mm} / \mathrm{ano}$ sendo o trimestre de dezembro a fevereiro o mais chuvoso (IBDF 1981).

O Parque está localizado no domínio fitogeográfico do Cerrado, em formações florestais, savânicas e campestres (IBDF 1981). Segundo Ribeiro \& Walter (1998), as formações florestais são compostas por mata seca semidecídua, mata ciliar e cerradão. Já as formações savânicas são compostas por cerrado s. str. e cerrado rupestre, enquanto as formações campestres são compostas por campo limpo, campo sujo e campo rupestre. Devido ao uso do fogo para manejo de pastagens, todas as formações florestais e savânicas existentes na região sofreram em diferentes graus algum tipo de alteração (IBAMA 2005).

Foram realizadas seis viagens de coleta ao PNSC. As coletas foram realizadas de forma assistemática, ao percorrer estradas e trilhas já existentes no PNSC. Os espécimes foram herborizados, identificados e incorporados ao herbário UEC e as duplicatas enviadas para o herbário ESA, HRCB e HUFU. Para verificar outras coletas, foram consultados os seguintes herbários, representados pelo acrônimo de acordo com Index Herbariorum (Thiers, continuously updated): BHCB, ESA, HRCB, HUFU, MBM, OUPR, RB, SP, SPF, SPFR, UEC, UPCB, VIC.

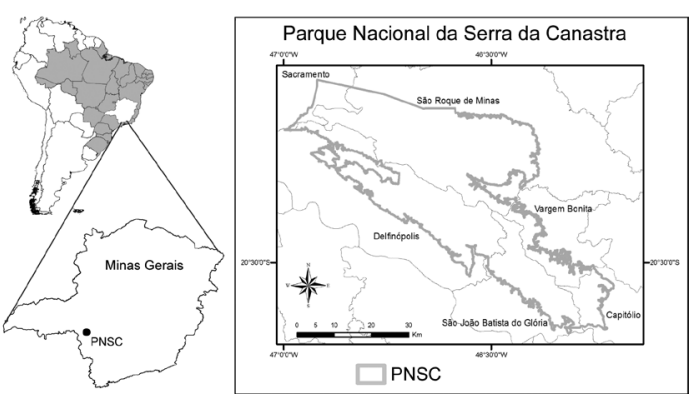

Figura 1 - Localização do Parque Nacional da Serra da Canastra na América do Sul e em Minas gerais. Figure 1- Location of Serra da Canastra National Park in South America and in Minas Gerais State (Brazil).

As descrições dos gêneros foram baseadas na literatura especializada sobre a família, enquanto as descrições das espécies foram elaboradas com base na análise do material coletado na região estudada. No caso da espécie ter sido pouco coletada ou estar em estado vegetativo, observouse material adicional de outras regiões. Descrições de gêneros e chaves para a identificação de espécies só são apresentadas para os gêneros representados por mais de uma espécie na área de estudo. Os termos morfológicos foram baseados em Radford et al. (1974) e, para as folhas, em Hickey (1973). As medidas foram tomadas sempre em órgãos maduros. No caso de comprimento e largura, foram utilizadas as respectivas medidas separadas por " $\mathrm{x}$ ".

\section{Resultados e Discussão}

Dentre as espécies encontradas, as lianas somam $40 \%$ e estão distribuídas em formações florestais: Forsteronia pubescens A. DC., Peltastes peltatus (Vell.) Woodson, Prestonia coalita (Vell.) Woodson, P. riedelii (Müll. Arg.) Markgr., sendo algumas específicas de mata ciliar: Condylocarpon isthmicum (Vell.) A. DC., Prestonia tomentosa R. Br., Secondatia densiflora A. DC. No entanto, Forsteronia velloziana (A. DC.) Woodson, Mandevilla hirsuta (A. Rich.) K. Schum e Mesechites mansoanus (A. DC.) Woodson ocorrem tanto em formações florestais como em formações savânicas. Temnadenia violacea (Vell.) Miers foi observada somente uma vez em campo rupestre, sendo bastante comum no cerrado s. str., juntamente com Odontadenia lutea (Vell.) Woodson. 
As espécies arbóreas somam 33,3\% do total. Destas, algumas ocorrem somente em formação florestal: Aspidosperma australe Müll. Arg., A. cylindrocarpon Müll. Arg., A. ramiflorum Müll. Arg., A. spruceanum Müll. Arg., Tabernaemontana catharinensis A. DC.; outras somente em formação savânica: A. macrocarpon Mart., Hancornia speciosa Gomes e Himatanthus obovatus (Müll. Arg.) Woodson; enquanto $A$. subincanum Mart. e A. tomentosum Mart. ocorrem nas duas formações. O hábito subarbustivo corresponde a $26,7 \%$ das espécies. Com exceção de Prestonia erecta (Malme) J.F. Morales, todas pertencem à Mandevilla, ocorrendo no cerrado $s$. str. e, principalmente, em formações campestres: M. illustris (Vell.) Woodson, M. longiflora (Desf.) Pichon, M. martii (Müll. Arg.) Pichon, M. novocapitalis Markgr., M. pohliana (Stadelm) Gentry, M. tenuifolia (J.C. Mikan) Woodson, M. velame (A. St.-Hil.) Pichon.

\section{Chave para identificação dos gêneros de Apocynaceae s. str.}

1. Corola com prefloração contorta sinistrorsa; ginostégio ausente

2 (Rauvolfioideae)

2. Lianas; lobos da corola longamente caudados; fruto articulado

2. Condylocarpon

2'. Árvores a arbustos; lobos da corola não caudados; fruto não articulado

4. Himatanthus

3. Ovário semi-ínfero

3'. Ovário súpero

1. Aspidosperma

4. Folhas geralmente alternas; sementes aladas

5. Folha sem nervuras secundárias paralelas entre si; sementes com arilo

5. Tabernaemontana

5'. Folha com nervuras secundárias paralelas entre si; sementes sem arilo

3. Hancornia

1'. Corola com prefloração contorta dextrorsa; estames adnatos à cabeça do estilete formando um ginostégio 6 (Apocynoideae)

6. Folhas peltadas 10. Peltastes

6'. Folhas não peltadas

11. Prestonia

7. Corola com anel caloso na fauce 7

7'. Corola sem anel caloso na fauce 9

8. Corola rotácea a sub-rotácea 6. Forsteronia

8'. Corola sub-hipocrateriforme a hipocrateriforme, infundibuliforme ou tubulosa ...... 10 9. Lacínias do cálice fortemente desiguais 9. Odontadenia

9'. Lacínias do cálice iguais ou similares 11

10. Cabeça do estilete umbraculiforme com projeções longitudinais ............. 12

1. Cabeça do estilete com 5 projeções longitudinais em toda sua extensão 7. Mandevilla

11'. Cabeça do estilete com 5 projeções longitudinais restritas à base 8. Mesechites

10'. Cabeça do estilete fusiforme, sem projeções longitudinais 13

12. Flores brancas, coléteres calicinais alternos na base da face adaxial; látex branco

12. Secondatia

12'. Flores violáceas, coléteres calicinais opostos na base da face adaxial; látex incolor 13. Temnadenia

Subfamília Rauvolfioideae

1. Aspidosperma Mart. \& Zucc. Flora 7 (1Beil.):135. 1824. nom. cons.

Árvores a arbustos. Coléteres nodais ausentes. Folhas geralmente alternas; coléteres laminares ausentes; nervação broquidódroma ou craspedódroma. Inflorescências dicásios modificados corimbiformes. Coléteres no cálice ausentes. Corola tubular ou hipocrateriforme. Ovário súpero, apocárpico; cabeça do estilete fusiforme a globosa. Folículos 2. Sementes aladas. Gênero neotropical, com 44 espécies distribuídas desde o México até a o norte da Argentina, com exceção do Chile (Kinoshita et al. 2005). 


\section{Chave de identificação para as espécies de Aspidosperma}

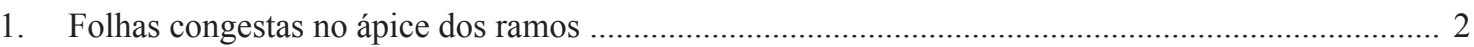

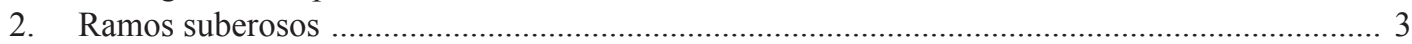

3. Frutos 9,3-14 × 7-9 cm; flores 1-1,6 cm compr.; pecíolo 1,8-3 cm compr.

1.3. A. macrocarpon

3'. Frutos 5-6,6 × 3,3-3,8 cm; flores $0,4-0,6 \mathrm{~cm}$ compr.; pecíolo menor que $0,5 \mathrm{~cm}$ compr. ....

1.7. A. tomentosum

2'. Ramos não suberosos

4. Lobos da corola iguais ou maiores que o tubo ....................................... 1.7. A. tomentosum

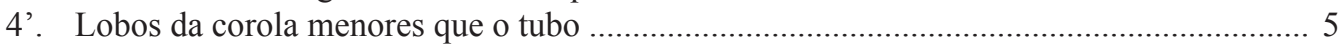

5. Folhas 6,5-12 × 2-3,1 cm, nervação broquidódroma ..........................1.1. A. australe

5'. Folhas 11-17 × 5-5-9 cm, nervação craspedódroma ..................... 1.6. A. subincanum

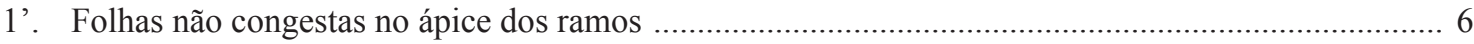

6. Inflorescência ramiflora ............................................................................. 1.4. A. ramiflorum

6'. Inflorescência axilar ou subterminal ....................................................................................... 7

7. Inflorescência axilar. Fruto piriforme, mucronado, pubescente, lenticelas inconspícuas; plantas com látex vermelho ............................................................................. 1.5. A. spruceanum

7’. Inflorescência subterminal. Fruto oblongo, não mucronado, glabro, lenticelas conspícuas; plantas com látex branco 1.2. A. cylindrocarpon

1.1. Aspidosperma australe Müll. Arg., in Martius \& Eichler, Fl. bras. 6(1): 58. 1860.

Árvores 5-10 m alt.; látex branco. Ramos não suberosos, lenticelados, jovens pubescentes e adultos glabros. Folhas congestas no ápice do ramo; pecíolos 1,7-3 cm compr., pilosos; lâminas 6,5-12 × 2-3,1 cm, elípticas, cartáceas, ápice agudo, base cuneada a atenuada, face adaxial glabrescente, estrigosa na nervura primária, face abaxial estrigosa; nervação broquidódroma. Inflorescências subterminais, pubescentes; pedúnculo 0,5-2,5 $\mathrm{cm}$ compr. Flores ca. $1 \mathrm{~cm}$ compr., amarelo-acinzentadas; pedicelo ca. $2 \mathrm{~mm}$ compr. Cálice com lacínias 1,6-2,1 ×0,9-1,2 mm deltóides, face adaxial vilosa somente na região apical, face abaxial vilosa. Corola hipocrateriforme; tubo 5-5,4 × 2-2,5 mm; lobos 1,8-2,2 $\mathrm{mm}$ compr., deltóides, patentes. Ovário tomentoso; cabeça do estilete oblonga. Folículos 5,3-5,7 × 2,6-3,1 $\mathrm{cm}$, dolabriformes, estipitados, não mucronados, lenticelas conspícuas, pubescentes. Sementes 3-3,7 × 2,0-2,6 cm, elípticas, núcleo seminífero central.

Material examinado: São Roque de Minas, Vão dos Cândidos, 6.IX.2008, fr., R. Morokawa et al. 225 (UEC). Material adicional: BRASIL. MINAS GERAIS: Araguari, Capim Branco II, 24.X.2007, fl., G.M. Araujo \& A.E. Gusson (UEC 148073).

Distribui-se em matas das Regiões Sudeste e Sul do Brasil (Kinoshita et al. 2005). No PNSC, foi coletada em áreas de pastagem. Espécie semelhante a A. olivaceum, mas diferindo desta por apresentar inflorescência com indumento acinzentado, enquanto A. olivaceum apresenta indumento amarelado. Coletado com frutos em setembro. Segundo Simões \& Kinoshita (2002), a espécie floresce de setembro a dezembro, com frutos podendo ser encontrados ao longo de todo o ano.

1.2. Aspidosperma cylindrocarpon Müll. Arg. in Mart., Fl. bras. 6(1): 54. 1860.

Árvores 5-12 m alt.; látex branco. Ramos não suberosos, fissurados, lenticelados, quando jovens pubescentes e adultos glabros. Folhas ao longo do ramo; pecíolos $2-3 \mathrm{~cm}$ compr., pilosos; lâminas $6,5-12 \times 2,3-5,8 \mathrm{~cm}$, elípticas ou oblongas, membranáceas, ápice acuminado, base obtusa, ambas as faces pilosas somente na nervura principal; nervação broquidódroma. Inflorescências subterminais, glabras; pedúnculo $0,5-2,5 \mathrm{~cm}$ compr. Flores $0,8-1 \mathrm{~cm}$ compr., amarelo-esverdeadas; pedicelo $1,2-3 \mathrm{~mm}$ compr. Cálice com lacínias $0,7-1 \times 0,7-0,9 \mathrm{~mm}$; deltóides, face adaxial vilosa na região dorsal e apical, face abaxial pilosa somente no ápice. Corola hipocrateriforme; tubo ca. $2,5 \times 1,5 \mathrm{~mm}$; lobos $6,5-$ $7 \mathrm{~mm}$ compr., lanceolados a lineares, suberetos. Ovário glabro; cabeça do estilete globosa. Folículos 6-8 × 2-2,5 cm, oblongos, curtamente estipitados, não mucronados, lenticelas conspícuas, glabros. Sementes 4-4,4 × 2,5-2,6 cm, oblongas a falciformes, núcleo seminífero lateral. 
Material examinado: São João Batista do Glória, Mata do Engenho, 3.IX.2008, fl., R. Morokawa et al. 218 (UEC). Material adicional: BRASIL. MINAS GERAIS: Araguari, Capim Branco I, 5.X.2005, fl., A.S. Siqueira \& V.H.P. Rodrigues (UEC 125924). Carrancas, Faz. do Sr. José Pinto, 1.X.1999, fl.e fr., A.O. Simões et al. 866 (UEC).

Distribui-se nas Regiões Centro-Oeste, Sudoeste e Sul do Brasil, e também na Bolívia, Paraguai e Peru (Kinoshita et al. 2005). No PNSC foi coletada em área de pastagem. Espécie facilmente reconhecida pelos lobos da corola longos, lineares, maiores que o tubo da corola; frutos oblongos, cilíndricos e sementes com núcleo seminífero basal. Coletado com flores em setembro. Segundo Kinoshita et al. (2005), a espécie floresce principalmente de setembro a novembro.

\subsection{Aspidosperma macrocarpon Mart., Flora 7(1),} Beibl. 4: 136. 1824.

Fig. 2a-e

Árvores 3-6 m alt.; látex branco. Ramos suberosos, fissurados, lenticelados, quando jovens com ápice lanoso. Folhas congestas no ápice do ramo; pecíolos 1,8-3 cm compr., lanosos; lâminas 19-35 × 14-25 cm, elípticas a ovais, coriáceas, ápice agudo a obtuso, base obtusa, face adaxial vilosa, glabrescente a glabra, face abaxial vilosa; nervação broquidódroma. Inflorescências subterminais, amarelo-velutinas; pedúnculo $1-3 \mathrm{~cm}$ compr. Flores 1-1,6 cm compr., esbranquiçadas; pedicelo ca. 1 mm compr. Cálice com lacínias 3-3,6 × 1-1,6 mm, estreito-triangulares, face adaxial pilosa e face abaxial glabra. Corola hipocrateriforme; tubo 6-8 $\times 3-4 \mathrm{~mm}$; lobos 6-10 mm compr., oblongos, patentes. Ovário glabro; cabeça do estilete globosa. Folículos 9,3-14 $\times 7-9 \mathrm{~cm}$, piriformes, estipitados, mucronados, lenticelas ausentes, velutinos. Sementes 7-8,2 $\times$ $6,7-8 \mathrm{~cm}$, orbiculares, núcleo seminífero concêntrico. Material selecionado: Delfinópolis, Claro, 14.IX.2000, fl., A.C.B. Silva 575 (SPFR); estrada para a Gurita, 3.XII.2002, fl. e fr., R.L. Volpi et al. 310 (HUFU, UEC); Fazenda Zé Antunes, 11.IV.2002, fr., R.A. Pacheco et al. 180 (HUFU, UEC); trilha da Escada de Pedra, 14.IX.2004, fl., C.A. Faria et al. 67 (HUFU, UEC).

Distribui-se no Peru, Bolívia, Paraguai e Brasil (PI, BA, Região Centro-Oeste, MG e SP) em Cerrado e Floresta Amazônica (Kinoshita et al. 2005). No PNSC foi coletado em campo rupestre e cerrado rupestre, é facilmente reconhecida em campo pelos ramos suberosos, frutos e folhas grandes de $19-35 \mathrm{~cm}$ de comprimento. Coletado com flores de setembro a dezembro, e com frutos de dezembro a maio. Segundo Kinoshita et al. (2005), a espécie floresce de julho a novembro, e frutifica de fevereiro a abril.
1.4. Aspidosperma ramiflorum Müll. Arg. in Mart., Fl. bras. 6(1): 55. 1860 .

Fig. 2f-g

Árvores 10-30 m alt.; látex branco. Ramos não suberosos, lenticelados, quando jovens pubérulos. Folhas ao longo do ramo; pecíolos 0,7-1,2 cm de compr., pilosos; lâminas 14,7-16,5 $\times 4,2-5,7 \mathrm{~cm}$, elípticas, cartáceas, ápice agudo, base aguda a cuneada, face adaxial glabra, pilosa sobre a nervura primária, face abaxial glabra; nervação broquidódroma. Inflorescências ramifloras, tomentosas; apenduculada. Flores 1,0-1,2 cm compr., brancas; pedicelo 0-1 mm compr. Cálice com lacínias 1,7-1,9 × 1-2 mm, deltóides, face adaxial glabra, face abaxial vilosa. Corola hipocrateriforme; tubo 9,6 × $3 \mathrm{~mm}$; lobos ca. $1,1 \mathrm{~cm}$ compr., oblongos, patentes. Ovário viloso; cabeça do estilete oblonga. Folículos 7,7-8,4 ×6,4-6,5 cm, piriformes, não estipitados, mucronados, lenticelas conspícuas, glabros. Sementes não observadas.

Material examinado: São Roque de Minas, Vão dos Cândidos, 6.IX.2008, fl. e fr., R. Morokawa et al. 226 (UEC).

Material adicional: BRASIL. MINAS GERAIS: Januária, Vale do rio Peruaçu, 20.VII.1997, fl., A. Salino 3264 (UEC).

Distribui-se em matas das Regiões Sudeste e Sul do Brasil e Bolívia (Kinoshita et al. 2005). No PNSC foi coletada em mata seca semidecídua. Coletado com flores e frutos em setembro. Segundo Kinoshita et al. (2005), a espécie floresce principalmente de julho a outubro, e frutifica de abril a novembro.

1.5. Aspidosperma spruceanum Benth. ex Müll. Arg. in Mart., Fl. bras. 6(1): 52. 1860. Fig. 2h Árvores 4-15 m alt.; látex vermelho. Ramos não suberosos, lenticelas ausentes nos ramos mais jovens, esparso-farinosos. Folhas ao longo do ramo; pecíolos 1-2,5 cm compr., pulverulentos; lâminas 5,5-12 × 2,2-5 cm, elípticas a oblongas, coriáceas, ápice agudo a acuminado, base atenuada, face adaxial pulverulenta na região da nervura primária, face abaxial canescente; nervação craspedódroma. Inflorescências axilares, tomentosas; pedúnculo 3-5 cm compr. Flores 0,6-0,8 cm compr., amarelas; pedicelo ca. $1 \mathrm{~mm}$ compr. Cálice com lacínias 1,7-2,2 × 1,2-1,5 mm, deltóides, tomentosas na face adaxial e no ápice da face abaxial. Corola hipocrateriforme; tubo $3,5 \times 1,8 \mathrm{~mm}$; lobos ca. 3 mm compr., lanceolados, eretos a suberetos. Ovário glabro; cabeça do estilete clavada. Folículos 8,8 $\times 5,8 \mathrm{~cm}$, piriformes, estipitados, mucronados, lenticelas inconspícuas, pubescentes. Sementes 5,2 $\times 5,5 \mathrm{~cm}$, orbiculares, núcleo seminífero central. 


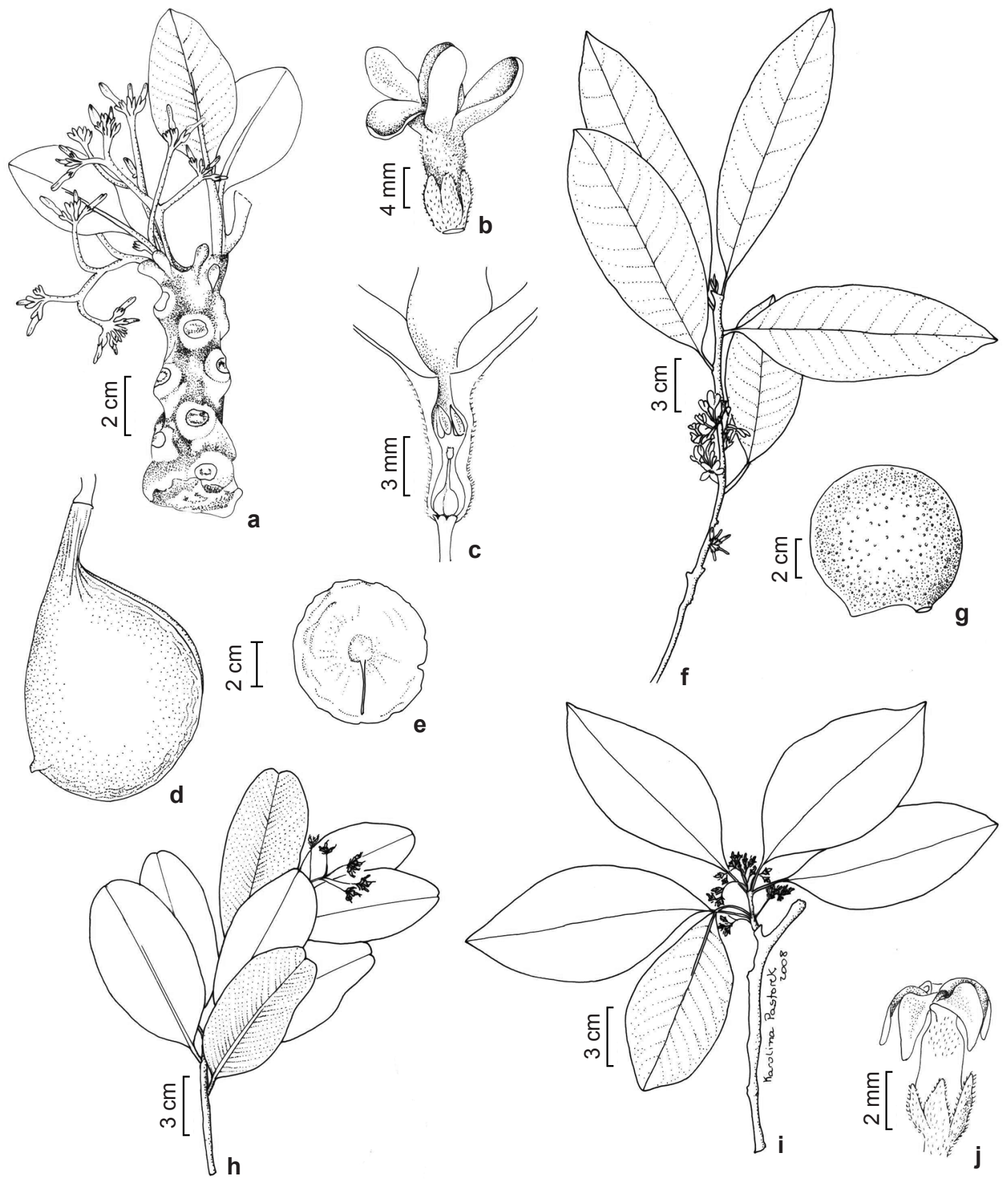

Figura 2 - a-e. Aspidosperma macrocarpon Mart. - a. ramo florífero; b. flor em vista lateral; c. flor em secção longitudinal; d. fruto; e. semente com núcleo seminal central. f-g. A. ramiflorum Müll. Arg. - f. ramo florífero; g. fruto. h. A. spruceanum Müll. Arg. - h. ramo florífero. i-j. A. subincanum Mart. - i. ramo florífero; j. flor em vista lateral. (a-c Silva 575; d-e Walter et al. (UEC52002); f Salino 3264; g Morokawa et al. 226; h-i Marcondes-Ferreira et. al. 875; j-k Morokawa et al. 224). Figure 2 - a-e. Aspidosperma macrocarpon Mart. - a. flowering branch; b. flower lateral view; c. flower in longitudinal section; d. fruit; e. seed with central nucleus seminal. f-g. A. ramiflorum Müll. Arg. - f. flowering branch; g. fruit. h. A. spruceanum Müll. Arg. - h. flowering branch. i-j. A. subincanum Mart. - i. flowering branch; j. flower in lateral view. (a-c Silva 575; d-e Walter et al. (UEC52002); f Salino 3264; g Morokawa et al. 226; h-i Marcondes-Ferreira et. al. 875; j-k Morokawa et al. 224). 
Material examinado: São Roque de Minas, 21.IX.1996, fr., J.N. Nakajima \& R. Romero 2061 (HUFU, UEC); 10.XII.1996, fr., W. Marcondes-Ferreira et al. 875 (UEC).

Distribui-se do México a São Paulo no Brasil (Kinoshita et al. 2005). No PNSC foi coletada em mata seca semidecídua. É facilmente reconhecida em campo pelo látex vermelho e ramos com indumento farinoso. Coletada com frutos de setembro a dezembro. Segundo Kinoshita et al. (2005), a espécie floresce o ano todo, com predominância no período de julho a setembro.

1.6. Aspidosperma subincanum Mart., Fl. bras. 20(2): 162. 1837.

Fig. 2i-j

Árvores 4-11 m de altura; látex branco. Ramos não suberosos, lenticelados, tomentosos no ápice. Folhas congestas no ápice do ramo, pecíolos 1,5-3,4 cm compr., seríceos; lâminas 11-17 × 5-5-9 cm, elípticas a obovais, membranáceas a cartáceas, ápice agudo a acuminado, base aguda a atenuada, face adaxial pilosa somente na nervura principal, face abaxial glabrescente, esbranquiçada; nervação craspedódroma. Inflorescências axilares, subterminais, tomentosas; pedúnculo 0,3-1,5 cm compr. Flores ca. 0,5 cm compr., brancoamareladas; pedicelo 1-1,5 mm compr. Cálice com lacínias 1,4-1,7 ×0,9 mm, triangulares, face adaxial tomentosa, face abaxial glabra. Corola com tubo ca. 4,2 × 1,5-2 mm; lobos 2,5-2,8 mm compr., ovais, reflexos. Ovário tomentoso; cabeça do estilete clavada. Folículos 6-7 × 3,3-4,2 cm, piriformes, curtamente estipitados, não mucronados, lenticela conspícuas, pulverulentos. Sementes ca. $4 \times 3 \mathrm{~cm}$, elípticas, núcleo seminífero central.

Material examinado: São João Batista do Glória, estrada da Mata do Engenho para São João Batista do Glória, 4.IX.2008, fl. e fr. R. Morokawa et al. 224 (UEC).

Material adicional: BRASIL. MINAS GERAIS. Coromandel, estrada Patrocínio-Coromandel, VIII.1999, fr., F.T. Farah 1048(UEC). Uberlândia, Estação Ecológica do Panga, 5.X.1989, fl., G.M. Araújo 586 (UEC).

Distribui-se no sudeste do Brasil (Kinoshita et al. 2005). No PNSC foi coletada em pastagem. Aspidosperma subincanum difere de $A$. tomentosum no comprimento dos lobos da corola que vão até a metade do tubo da corola e ovário tomentoso; enquanto que em $A$. tomentosum os lobos são de igual comprimento ou maiores que o tubo da corola e o ovário é glabro. Coletado com flores e frutos em setembro. Segundo Woodson (1951) flores de setembro a novembro.
1.7. Aspidosperma tomentosum Mart., Flora 7(1), Beibl. 4: 135. 1824.

Árvores 1,9-5 m de altura; látex branco. Ramos suberosos ou não, fissurados ou não, lenticelados, tomentosos na região de inserção das folhas, ápice densamente amarelo-viloso. Folhas congestas no ápice do ramo; pecíolos menores que $0,5 \mathrm{~cm}$ compr., tomentosos; lâminas $12,5-25,5 \times$ $4,3-9,4 \mathrm{~cm}$, elípticas ou obovais, membranáceas a coriáceas, ápice agudo, base atenuada, face adaxial esparso tomentosa, face abaxial tomentosa; nervação craspedódroma. Inflorescências axilares, subterminais, tomentosas; pedúnculo $1,3-2,1 \mathrm{~cm}$ compr. Flores $0,4-0,6 \mathrm{~cm}$ compr., brancas com fauce amarela; pedicelos $0-0,5 \mathrm{~mm}$ compr. Cálice com lacínias 2,5-4 × 0,9-1,5 mm, lanceoladas, densamente tomentosas na face adaxial e no ápice da face abaxial. Corola com tubo 3,3-4,3 × 1,5-1,9 $\mathrm{mm}$; lobos 3,5-6 mm compr., oblongos, patentes. Ovário glabro; cabeça do estilete clavada. Folículos $5-6,6 \times 3,3-3,8 \mathrm{~cm}$, piriformes, curtamente estipitados, não mucronados, lenticelas conspícuas, ferrugíneo-tomentosos quando jovens, glabros quando adultos. Sementes $4-4,4 \times 2,5-2,6 \mathrm{~cm}$, elípticas, núcleo seminífero central.

Material selecionado: Delfinópolis, Trilha do Zé Carlinho, 9.X.2002, fl., J. Nakajima et al. 3202 (HUFU). São Roque de Minas, estrada para Retiro de Pedras, 16.XI.2007, fl., R. Morokawa et al. 127 (UEC). São João Batista do Glória, Mata do Engenho, fl., 3.IX.2008, $R$. Morokawa et al. 219 (UEC).

Amplamente distribuída no Brasil e Paraguai (Kinoshita et al. 2005). No PNSC foi coletada em formações de cerrado e mata seca semidecídua. Os espécimes de cerrado possuem ramos suberosos enquanto os de mata seca semidecídua apresenta ramos não suberosos. Coletado com flores de setembro a novembro, e também em maio, e com frutos em abril e setembro. Segundo Simões \& Kinoshita (2002), a espécie floresce de setembro a outubro, com frutos podendo ser encontrados ao longo de todo o ano.

2. Condylocarpon isthmicum (Vell.) A. DC., Prodr. 8: 381.1844.

Lianas. Ramos jovens curto-pubescentes, adultos glabros. Folhas verticiladas 3 por nó e às vezes opostas; pecíolos $0,6-2,2 \mathrm{~cm}$ compr., pubérulos; lâminas 4,7-11 × 2,2-5,3 cm, elípticas ou obovais, membranáceas a cartáceas, ápice acuminado ou cuspidado, base aguda a obtusa, face adaxial glabra a esparso pubescente, face abaxial esparso pubescente com domácias pilosas nas axilas 
da nervura primária; nervação broquidódroma. Inflorescências tirsiformes, terminais, esparsopubescentes; pendúnculo $2,8-5 \mathrm{~cm}$ compr. Flores $0,4-0,5 \mathrm{~cm}$ compr., amarelas a alaranjadas; pedicelo 1-3 mm compr. Cálice com lacínias ca. 0,7 ×0,6 mm, amplamente ovais, glabras. Corola hipocrateriforme; tubo 1,6-2,4 × 1,2-1,3 mm; lobos ca. 3,4 mm compr., oblíquos, longamente caudados no ápice, patentes. Ovário súpero, hemissincárpico, glabro; cabeça do estilete orbicular. Mericarpos ca. $12 \times 0,6-1,6 \mathrm{~cm}$, articulados, pubescentes quando imaturos, glabros quando maduros. Sementes 0,9-1 cm compr, nuas. Material selecionado: Delfinópolis, estrada para Gurita, 9.III.2003, fr., R. Romero et al. 6703 (HUFU). São Roque de Minas, Retiro de Pedras, 13.X.2007, fl., R. Morokawa et al. 116 (UEC); trilha para a cachoeira Casca d'anta, 11.X.2007, fl., R. Morokawa et al. 100 (UEC).

Distribui-se do Ceará no Brasil até a Argentina (Fallen 1983). No PNSC foi coletado em bordas de mata ciliar. É facilmente reconhecível em campo pelas folhas verticiladas e a presença de domácias pilosas nas axilas da nervura primária. Coletado com flores em outubro e novembro, e com frutos de novembro a março. Segundo Simões \& Kinoshita (2002), a espécie floresce de setembro a março, e frutifica de setembro a dezembro.

\section{Hancornia speciosa Gomes, Obs. Bot. Med.} Bras. Pl. 2:3. 1803.

Fig. 3a

Árvores 1,8-5 m alt; látex branco. Ramos não suberosos, lenticelados, glabros. Folhas distribuidas ao longo do ramo; pecíolos $0,3-6 \mathrm{~cm}$ compr., glabros; lâminas 4,4-8,5 × 2,4-3,5 cm, oblongas a elípticas, cartácea, ápice agudo, retuso e acuminado, base aguda a arredondada, em ambas as faces glabra; nervação craspedródoma. Inflorescências dicasios, terminais, pubescentes; apendunculado. Flores 3,3-4,2 cm compr., amarelas; pedicelos 4-10 mm compr. Cálice com lacínias 19-27× 16-18 mm, deltóides, face adaxial glabra, face abaxial pubescente. Corola com tubo 30-35 × 3-4 mm; lobos 13-15 mm de compr, oblíquo-lineares, patentes. Ovário súpero, sincárpico, glabro; cabeça do estilete oblonga lanceolada. Bagas 3,2-4 × 2,9-5 cm, globosas, amarelo-alaranjadas, pulverulentas em algumas regiões. Sementes $0,7-1,1$ $\times 0,3-0,6 \mathrm{~cm}$, nuas.

Material selecionado: Delfinópolis, estrada para Gurita, 7.X.2002, fl. e fr., R. Romero et al. 6402 (HUFU); Fazenda ZéAntunes, 26.XI.2003, fl., R. Romero et al. 6956 (HUFU); região da Represa de Furnas, 7.XII.2005, fl., J. Nakajima et al. 4025 (HUFU); região da Represa de Furnas 29.IX.2005, fr., R. Romero et al. 7239 (HUFU, UEC).
Amplamente distribuída no Brasil do sudoeste do Amazonas até o Paraná, principalmente em áreas de cerrado (Kinoshita et al. 2005). No PNSC foi coletado em campo rupestre e cerrado rupestre. É facilmente reconhecível pela folha com numerosas nervuras secundárias paralelas entre si e pelo fruto do tipo baga. Coletado com flores de outubro a dezembro, e com frutos de setembro a maio. Segundo Simões \& Kinoshita (2002), a espécie floresce e frutifica de novembro a fevereiro.

4. Himatanthus obovatus (Müll. Arg.) Woodson, Ann. Missouri Bot. Gard. 25(1): 201. 1938.

Fig. 3b-c

Arvoreta 2-3 m alt. Ramos suberosos, glabros. Folhas congestas no ápice dos ramos; pecíolos 0,3-0,6 cm compr., glabros ou esparso-pubescentes; lâminas $12-21,5 \times 7,3-13,5 \mathrm{~cm}$, ovais a obovais, coriáceas, ápice acuminado a agudo, base aguda, face adaxial pilosa, face abaxial glabra; nervação broquidódroma. Inflorescências cincinios dicotômicos, terminais, glabras; pendúnculo 3,5-6 cm compr. Flores 3,2-4 cm compr., brancas; pedicelos 6,4-7,3 mm compr. Cálice com uma lacínia maior 5-6,3 × 2,3-2,5 mm, três menores 1,5-2,2 × 1-1,2 mm, e uma bastante reduzida ca. $1 \mathrm{~mm}$ compr., ovais, glabras. Corola com tubo 16-17 × 28-35 mm; lobos 29-33 mm compr., elípticos, patentes. Ovário semi-ínfero, apocárpico, glabro; cabeça do estilete fusiforme. Folículos 10-21 $\times 1,9-2,9 \mathrm{~cm}$, costa proeminente, glabros. Sementes $3,2-4,5 \times 1,8-2,4 \mathrm{~cm}$, aladas.

Material examinado: Capitólio, Região da Represa de Furnas, 22.V.2007, fl., J.N. Nakajima et al. 4473 (HUFU). Delfinópolis, Vale da Babilônia, 10.XII.2008, M.F. Silveira et al. 86 (UEC).

Material adicional: BRASIL. MINAS GERAIS: Uberlândia, ca. $35 \mathrm{~km}$ da cidade em direção a Uberaba, 15.IV.2001, fl., R. Schütz Rodrigues \& A. Flores 1173 (UEC).

Distribui-se na Bolívia e Brasil (MA, PI, AL, BA, MT, MS, GO, MG e SP) em cerrado, campo rupestre, restinga e mata ciliar (Kinoshita et al. 2005). No PNSC foi coletado em campo rupestre e cerrado s. str. É reconhecida em campo por suas folhas obovais, e inflorescência robusta e bracteada. Coletado com flores em maio e dezembro. Segundo Kinoshita et al. (2005), a espécie floresce de setembro a abril e frutifica de maio a julho.

5. Tabernaemontana catharinensis A. DC., Prodr. 8: 365.1844.

Fig. 3d-e

Árvores 3-6 m alt; látex branco. Ramos não suberosos, lenticelados, pubescentes no ápice. Folhas ao longo do ramo; pecíolos 0,2- 

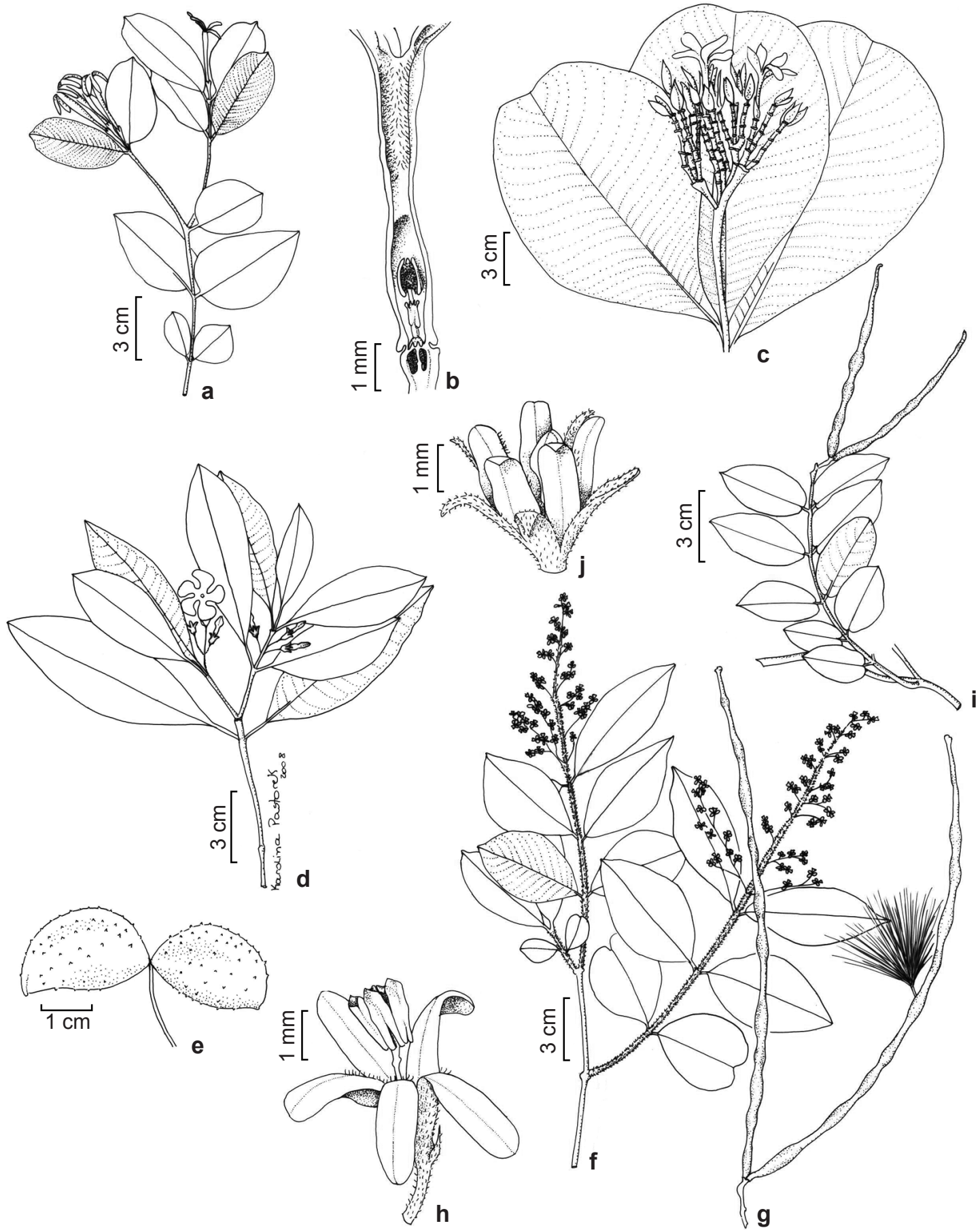

Figura 3 - a. Hancornia speciosa Gomes - a. ramo. b-c. Himatanthus obovatus (Müll. Arg.) Woodson - b. tubo da corola em secção longitudinal; c. ramo florífero. d-e. Tabernaemontana catharinensis A. DC. - d. ramo florífero; e. fruto. f-h. F. pubescens A. DC. -f. ramo florífero; g. fruto; h. flor. i-j. Forsteronia. velloziana (A. DC.) Woodson-i. ramo com fruto; j. flor. (a Romero et al. 6402; b-c Schütz Rodrigues \& Flores 1173; d Joly et al. 16504; e Rosa et al. 490; f Simões \& K. Matsumoto 703; g Morokawa et al. 153; h, j Rosa et al. 866; i Bernacci et al. 54).

Figure 3 - a. Hancornia speciosa Gomes - a. branch. b-c. Himatanthus obovatus (Müll. Arg.) Woodson - b. corolla tube in longitudinal section; c. flowering branch. d-e. Tabernaemontana catharinensis A. DC. - d. flowering branch; e. fruit. f-h. F. pubescens A. DC. - f. branch flowering; g. fruit; h. flower. i-j. Forsteronia. velloziana (A. DC.) Woodson - i. branch with furit; j. flower. (a Romero et al. 6402; b-c Schütz Rodrigues \& Flores 1173; d Joly et al. 16504; e Rosa et al. 490; fimões \& K. Matsumoto 703; g Morokawa et al. 153; h, j Rosa et al. 866; i Bernacci et al. 54). 
0,4 cm compr., tomentosos; lâminas 9-11,5 × 2-3,5 cm, elípticas, cartáceas, ápice agudo a acuminado, base cuneada, face adaxial glabra ou com nervura primária pubescente, face abaxial glabra ou pubescente; nervação broquidódroma. Inflorescências cimosas, axilares, glabras; pedúnculo $0,8-1 \mathrm{~cm}$ compr. Flores $0,8-1 \mathrm{~cm}$ compr., brancas; pedicelo 5,2-7 $\mathrm{mm}$ compr. Cálice com lacínias 3,2-5 × 1-2,1 mm, estreitotriangulares, pubescentes, coléteres contínuos. Corola hipocrateriforme, tubo 8,7-9,3 × 2,6-3,4 $\mathrm{mm}$; lobos 9-11 mm compr., obliquamente estreitoolongos, patentes. Ovário súpero, apocárpico, glabro; cabeça do estilete cilindrica com 5-10 projeções na base. Folículos 1,7-2,8 × 1-1,9 cm, muricados, glabros. Sementes ca. $0,7 \times 0,4 \mathrm{~cm}$, com arilo amarelo em frutos imaturos e avermelhados em frutos maduros.

Material examinado: Capitólio, região de Furnas, 20.III.2007, fl., P.O. Rosa et al. 490 (HUFU, UEC).

Material adicional: BRASIL. SÃO PAULO: Brotas, beira do rio Jacarei, 26.IV.1984, fr., C.A. Joly et al. 16504 (UEC). Itú, Praça da Independência, 27.XI.1989, fl., S. Bruni (UEC88044).

Distribui-se Brasil (Regiões Nordeste, Sudeste e Sul), Bolívia, Uruguai, Paraguai e nordeste da Argentina (Kinoshita et al. 2005). No PNSC foi coletada em mata seca semidecídua. Espécie facilmente reconhecida quando em frutificação, pois os frutos são muricados e deiscentes, e pelo arilo laranja-avermelhado recobrindo as sementes. Coletado com flores em março. Segundo Leeuwenberg (1994), a espécie floresce de outubro a novembro, com pico de frutificação em maio e junho.

\section{Subfamilia Apocynoideae}

6. Forsteronia G. Mey., Prim. Fl. Esseq.: 133. 1818.

Lianas; látex branco. Ramos com coléteres nodais, estípulas ausentes. Folhas opostas, raro verticiladas, usualmente com domácias pubescentes nas axilas da nervura primária; coléteres na base da face adaxial da nervura primária; nervação broquidódroma. Inflorescências tirsiformes, multifloras. Pedicelos retos. Cálice com lacínias iguais; coléteres alternos ou opostos às lacínias. Corola rotácea a sub-rotácea. Estames inclusos a exclusos. Cabeça do estilete fusiforme. Folículos 2. Sementes elípticas a lineares. Gênero neotropical com 46 espécies, no Brasil ocorre 26 espécies (Kinoshita et al. 2005).

\section{Chave de identificação para as espécies de Forsteronia}

1. Inflorescência menor que as folhas subsequentes; lacínias do cálice iguais ou maiores que $4 \mathrm{~mm}$ de compr.; ápice do folículo não dilatado 6.2. F. velloziana

1'. Inflorescência maior que as folhas subsequentes; lacínias do cálice menores que $2 \mathrm{~mm}$ de compr.; ápice do folículo dilatado 6.1. F. pubescens

6.1. Forsteronia pubescens A. DC., Prodr. 8: 436. 1844.

Fig. 3f-h

Ramos tomentosos quando jovens, glabros quando adultos. Folhas opostas; pecíolos $0,4-0,8$ cm compr., tomentosos; lâminas 5,5-12,4 $\times$ 2,3-5,6 cm, elípticas, oblongas, cartáceas, ápice acuminado, base obtusa a arredondada, face adaxial glabra a pubescente, face abaxial tomentosa, com domácias pubescentes nas axilas da nervura central. Inflorescências terminais, maiores que as folhas subsequentes; pedúnculo $0,7-1 \mathrm{~cm}$ compr.; brácteas $1-2 \mathrm{~mm}$ compr., ovais a lanceoladas, tomentosas. Flores ca. 0,5 cm compr, branco-creme; pedicelos 0,7-0,9 mm. Cálice com lacínias 1-1,4 × 0,7-1 mm, deltóides, coléteres opostos. Corola sub-rotácea; tubo 0,7-1 × 1,9-2 $\mathrm{mm}$; lobos 4-5 mm compr., liguliformes, patentes.
Estames exclusos; anteras oblongas, base sagitada, ápice apiculado; filetes conatos. Disco nectarífero 5-lobado. Ovário pubescente. Folículos 13-20,5 $\times 0,4-0,5 \mathrm{~cm}$, submoniliformes, ápice dilatado. Sementes $0,9-1,3 \times 0,2 \mathrm{~cm}$, cilíndricas, glabras; coma 4-5 cm compr.

Material examinado: São Roque de Minas, entrada da Usina Jaraguá, 19.XI.2003, fr., S.M. Gomes et al. 717 (UEC).

Material adicional: BRASIL. MINAS GERAIS: Uberlândia, Capim Branco II, 10.IX.2007, fl., P.O. Rosa et al. 866 (UEC). SÃO PAULO: São Paulo, Tietê, Instituto Agronômico, 20.VII.1994, fr., L.C. Bernacci et al. 544 (UEC).

Amplamente distribuída, do Peru ao norte da Argentina e Brasil (CE, BA, MT, MG e SP) (Kinoshita et al. 2005). No PNSC foi encontrada em cerrado s. str. Coletado com frutos em 
novembro. Segundo Kinoshita et al. (2005), a espécie floresce de setembro a novembro e frutifica de novembro a agosto.

6.2. Forsteronia velloziana (A. DC.) Woodson, Ann. Missouri Bot. Gard. 21 (4): 622. 1934.

Fig. $3 f-g$

Ramos quando jovens ferrúgineopubescentes. Folhas opostas; pecíolos $0,2-0,4$ cm compr., pubescentes; lâminas $2-5 \times 1,2-2,5$ $\mathrm{cm}$, elípticas, obovais, oblongas, membranáceas, ápice agudo a acuminado, cuspidado, base obtusa ou cordiforme, ambas as faces pubescentes principalmente ao longo das nervuras, domácias ausentes. Inflorescências terminais, menores que as folhas subsequentes; pedúnculo $0,2-0,7$ $\mathrm{cm}$ compr.; brácteas $4-7 \mathrm{~mm}$, lanceoladas, pubescentes. Flores ca. 0,5 cm compr., brancoesverdeadas; pedicelos 1,5-2,5 mm compr, retos. Cálice com lacínias 4-4,6 × 1-1,5 mm, iguais, linear-lanceoladas, coléteres opostos. Corola subrotácea; tubo ca. $1 \times 3 \mathrm{~mm}$; lobos $2,8 \mathrm{~mm}$ compr., oblongos, eretos. Estames parcialmente exclusos; anteras lanceoladas, apiculadas, base sagitada; filetes não conatos. Disco nectarífero 5-lobado. Ovário pubescente. Folículos 7,5-9 × 0,3-0,5 cm, cilíndricos a submoniliformes, ápice não dilatado. Sementes $0,7-0,9 \times 0,2 \mathrm{~cm}$, estreitamente elípticas, pubescentes; coma 2-4 cm compr.

Material examinado: São Roque de Minas: trilha da parte de cima Casca d'anta, 11.X.2007, fl., R. Morokawa et al. 103 (UEC); São José do Barreiro, trilha Casca d'anta, 19.XI.2007, fl., R. Morokawa et al. 153 (UEC).
Material adicional: BRASIL. MINAS GERAIS: Carrancas, Serra de Carrancas, 24.I.1999, fr., A.O. Simões e K. Matsumoto 703 (UEC).

Distribui-se de Minas Gerais a Santa Catarina (Hansen 1985). No PNSC foi encontrada em campo rupestre, cerrado s. str. e mata ciliar. Coletado com flores em outubro e novembro. Segundo Simões \& Kinoshita (2002), a espécie floresce de setembro a novembro, e frutifica de outubro a março.

7. Mandevilla Lindl., Edwards's Bot. Reg. 26: pl. 7. 1840, nom cons.

Lianas, subarbustos, arbustos eretos a escandentes; látex branco. Ramos com coléteres nodais, estípulas ausentes. Folhas geralmente opostas; coléteres presentes na face adaxial da lâmina ou ao longo de toda a nervura primária ou ausentes; domácias ausentes. Inflorescências racemosas. Pedicelos retos. Cálice com lacínias iguais a subiguais; coléteres alternos, opostos ou contínuos. Corola infudibuliforme, hipocrateriforme, subhipocrateriforme ou tubular. Cabeça do estilete umbraculiforme, com 5 projeções longitudinais em toda sua extensão. Folículos 2. Sementes lineares a estreito-elípticas. Gênero neotropical, com cerca de 150 espécies distribuídas do sudoeste dos Estados Unidos à Argentina em uma grande variedade de habitats como os desertos, savanas, tepuís, campos e florestas (Simões et al. 2006). Recentemente a circunscrição de Mandevilla foi ampliada com a inclusão de Macrosiphonia Müll.Arg., Quiotania Zaruqui e Telosiphonia (Woodson) Herinckson como sinônimos (Simões et al. 2006; Simões et al. 2007).

\section{Chave de identificação para as espécies de Mandevilla}

1. Lianas, flores amarelas 7.1. M. hirsuta

1'. Subarbustos, flores róseas a vináceas ou brancas .................................................................... 2

2. Folhas albo-lanosas; flores brancas ................................................................................ 3

3. Folha com ambas as faces albo-lanosas .................................................... 7.8. M. velame

3'. Folha com apenas a face abaxial albo-lanosa .................................................................. 4

4. Inflorescência com até 2 flores ....................................................... 7.3. M. longiflora

4'. Inflorescência com 8-18 flores .............................................................. 7.4. M. martii

2'. Folhas glabras, pubescente, tomentosas ou velutinas; flores róseas a vináceas .......................... 5

5. Lâmina foliar glabra em ambas as faces, coléter ausente .................. 7.5. M. novocapitalis

5'. Lâmina foliar pubescente, tomentosa ou velutina em ambas as faces, coléter presente ..... 6

6. Flor ca. $2 \mathrm{~cm}$ de comprimento; corola hipocrateriforme ................... 7.7. M. tenuifolia

6'. Flor 3 a $7 \mathrm{~cm}$ de comprimento; corola infundibuliforme ............................................ 7

7. Tubo superior infudibuliforme, $9-15 \times 6-15 \mathrm{~mm}$........................ 7.2. M. illustris

7'. Tubo superior cilíndrico, $25-30 \times 10-15 \mathrm{~mm}$............................ 7.6. M. pohliana 
7.1. Mandevilla hirsuta (Rich.) K. Schum. in Engl. \& Prantl, Nat. Pflanzenfam. 4(2): 171. 1895.

Lianas. Ramos hirsutos. Folhas opostas; pecíolos 0,4-1,2 cm compr., hirsutos; lâminas 7-13 × 3-6,5 cm, elípticas a oblongas, cartáceas, ápice agudo a acuminado, base lobada, face adaxial estrigosa, face abaxial hirsuta; coléteres na face adaxial ao longo de toda a nervura primária; nervação broquidódroma. Inflorescências axilares, 5-19-floras; pedúnculo 1-5 cm compr.; brácteas 16-25 mm compr., elípticas a rombóides, pilosas. Flores 6-7,5 cm compr., levemente zigomorfas, amarelas com fauce vermelha; pedicelos 2-3 mm compr. Cálice com lacínias 9-19 × 1,5-2,5 $\mathrm{mm}$, lanceoladas; coléteres opostos. Corola infundibuliforme; tubo inferior 2,1-2,2 × 0,3-0,7 $\mathrm{mm}$, cilíndrico, levemente giboso na base; tubo superior 21-25 × 16-20 mm, infundibuliforme; lobos 22-27 mm compr., oval-oblíquos ou deltóides. Disco nectarífero 5 lobado. Ovário minutamente piloso. Folículos 10-12,5 ×0,5 cm, unidos no ápice, levemente torulosos, hirsutos. Sementes ca. $1 \times 0,3$ $\mathrm{cm}$, pubescentes; coma ca. 1,5 cm compr.

Material selecionado: Capitólio, região da Represa de Furnas, 23.V.2007, fl., J. Nakajima et al. 4510 (HUFU, UEC). Delfinópolis, Vale da Babilônia, Pousada Babilônia, 8.XII.2008, fl. e fr., M.F. Silveira et al. 40 (UEC). São Roque de Minas, Cachoeira dos Rolinhos, 29.VI.1997, fr., $R$. Romero et al. 4358 (HUFU, UEC); trilha Casca d'anta, 20.XII.2007, fl., R. Morokawa et al. 178 (UEC).

Distribui-se na América Central, incluindo Antilhas até o SE do Brasil em mata de encosta, restinga, cerrado e campo rupestre (Kinoshita et al. 2005). No PNSC foi coletada em borda de mata seca semidecídua, mata ciliar e campo rupestre. Espécie reconhecida em campo pelas flores levemente zigomorfas devido à curvatura do tubo inferior e pelos frutos unidos no ápice e hisurtos. Coletado com flores de maio a dezembro, e com frutos de junho a dezembro. Segundo Simões \& Kinoshita (2002) e Morales (2005a), a espécie pode ser coletada com flores e frutos ao longo de todo o ano.

7.2. Mandevilla illustris (Vell.) Woodson, Ann. Missouri Bot. Gard. 20(4): 727. 1933.

Subarbustos eretos, $0,2-0,8 \mathrm{~m}$ alt. Ramos pubescentes. Folhas opostas; pecíolos $0-4 \mathrm{~mm}$ compr., pubescentes; lâminas 3,5-10,2 × 2,4$10,2 \mathrm{~cm}$, elípticas a orbiculares, cartáceas, ápice acuminado, base cuneada, ambas as faces pubescentes a velutinas; coléteres na base da nervura central na face abaxial; nervação boquidódroma. Inflorescências terminais, (1-)4-8-flora; pedúnculo 2-8 mm compr.; brácteas 5-15 mm compr., estreito-triangulares, face adaxial glabra, face abaxial com tricomas avermelhados. Flores 3,1-6,3 cm compr., róseas com fauce mais escura estendendo-se para os lobos em forma de estrela ou fauce branca; pedicelos 8-19(-33) mm compr. Cálice com lacínias 8-9 $\mathrm{mm}$ compr., estreito-triangulares, coléteres alternos. Corola infudibuliforme; tubo inferior 10-14 × 1-4 $\mathrm{mm}$, cilíndrico; tubo superior 9-15 × 6-15 mm, infundibuliforme; lobos 30-31 mm compr., oblíquoobovais. Disco nectarífero 2 alternocarpelares. Ovário glabro. Folículos 18-26×0,3-0,4 cm, livres no ápice. Sementes ca. $0,8 \times 0,2 \mathrm{~cm}$; coma 4-4,5 cm compr. Material selecionado: Capitólio, região da Represa de Furnas, 25.X.2006, fl., J. Nakajima et al. 4250 (HUFU). Delfinópolis, Fazenda Zé Antunes, 26.XI.2003, fl., $J$. Nakajima et al. 3707 (HUFU, UEC). São Roque de Minas, Retiro de Pedras, 16.XI.2007, fl., R. Morokawa et al. 129 (UEC).

Distribui-se no Brasil (Centro-Oeste, MG, SP, PR) e Paraguai em planaltos e montanhas com vegetação de cerrado e campo rupestre (Kinoshita et al. 2005). No PNSC foi coletada em cerrado s. str., campo sujo, campo limpo, mata seca semidecídua e mais raramente em campo rupestre. A espécie é reconhecida pelo desenho formado na fauce da corola de uma estrela rósea, raro ausente. Coletado com flores de outubro a janeiro, e com frutos de janeiro a julho. Segundo Sales (1993), a espécie floresce de outubro a janeiro.

7.3. Mandevilla longiflora (Desf.) Pichon, Bull. Mus. Natl. Hist. Nat., sér. 2, 20: 107. 1948.

Subarbustos eretos, 0,3-0,7 m alt. Ramos albo-lanosos. Folhas opostas; pecíolos 1,5-4 cm compr., lanosos; lâminas 1,5-6,5 ×0,5-3 cm, ovais a elípticas, cartáceas, ápice acuminado, base obtusa, face adaxial esparsamente lanosa, face abaxial albo-lanosa; coléteres na base da face adaxial; nervação broquidódroma. Inflorescências axilares, 1-2-flora; pedúnculo 10-24 cm compr.; brácteas 3-10 mm compr., filiformes, pilosas. Flores 12-17 $\mathrm{cm}$ compr., brancas, esverdeadas a amareladas, com fauce amarela; pedicelos 4-7 mm compr. Cálice com lacínias 15-25 × 2-3 mm, lanceoladas, coléteres contínuos. Corola hipocrateriforme; tubo inferior 10-15 $\times 2-4 \mathrm{~cm}$, cilíndrico; tubo superior 15-25 × 15-30 mm, campanulado; lobos 22-32 mm compr., obovais. Disco nectarífero 5 lobado. Ovário glabro. Folículos 12-22 cm compr., livres no ápice, torulosos, velutinos quando jovens e tomentosos quando adultos. Sementes $0,8-1 \times 0,3$ cm; coma 1,3-1,8 cm compr. 
Material selecionado: São Roque de Minas, $3 \mathrm{~km}$ da sede, 16.IV.1994, fr., R. Romero et al. 875 (UEC); estrada para Cachoeira dos Rolinhos, 26.IX.1995, fl., R. Romero et al. 1860 (HUFU); estrada da portaria de São Roque de Minas a Sacramento, 12.X.2007, fl., R. Morokawa et al. 105 (UEC); Torre de Observação, 1.XI.2004, fl., M.A. Farinaccio et al. 189 (HUFU).

Distribui-se na Argentina, Bolívia, Brasil (Regiões Centro-Oeste e Sul, MG e SP), Paraguai e Uruguai, em cerrado, campo limpo e campo de altitude (Barban 1985). No PNSC foi coletada em campo limpo e campo rupestre. Coletado com flores de setembro a dezembro, e com frutos de novembro a abril. Segundo Kinoshita et al. (2005), a espécie floresce o ano todo, com predominância nos meses de setembro a dezembro, e frutifica de outubro a maio.

7.4. Mandevilla martii (Müll. Arg.) Pichon, Bull. Mus. Natl. Hist. Nat., sér. 2, 20: 107. 1948

Fig. $4 \mathrm{a}$

Subarbustos eretos, $0,85-1,16 \mathrm{~m}$ alt. Ramos albo-tomentosos. Folhas opostas; pecíolos 0,2-1 cm compr., seríceos; lâminas 4-9 × 2,3-5 cm, ovais a oblongas, coriáceas, ápice agudo, mucronado, base truncada a lobada, face adaxial tomentosa, face abaxial albo-lanosa; coléteres na base da nervura primária da face adaxial; nervação broquidódroma. Inflorescências terminais, às vezes axilares, 8-18-flora; pedúnculo 26-34 cm compr.; brácteas 3,5-8,5 mm compr., filiformes, tomentosas. Flores 10-14 cm compr., brancoesverdeadas com fauce amarela; pedicelos 4,5-7 mm compr., lanosos. Cálice com lacínias 15-25 × 2-3 mm, estreito-lanceoladas; coléteres opostos. Corola hipocrateriforme; tubo inferior 6-8,6 $\times$ 0,3-0,4 cm, cilíndrico; tubo superior $2-3 \times 0,8-0,9$ cm, cilíndrico; lobos ca. 2,4-2,8 cm compr., obovais. Disco nectarífero 5 lobado. Ovário glabro ou piloso. Frutos e sementes não observados.

Material examinado: Delfinópolis, Claro, 10.I.2000, fl., A.C.B. Silva \& L.R. Reato 864 (SPFR). São Roque de Minas, 12.I.1994, fl., A.M. Giulietti et al. (ESA 23062). Material adicional: BRASIL. GOIÁS: Catalão, estrada para Cristalina, 6.XI.2002, fl., A.O. Simões et al. 1190 (UEC). Colinas do Sul, estrada para a Serra da Mesa, 10.XI.2002, fl., A.O. Simões et al. 1229 (UEC). MINAS GERAIS: Coromandel, Douradinho, 5.I.1988, fl., A. Reis et al. 730 (UEC).

Distribui-se no Brasil (GO, DF e MG), em cerrado, campo limpo e campo rupestre (Barban 1985). No PNSC foi coletada em cerrado s. str. Coletado com flores em janeiro. Segundo Kinoshita et al. (2005), a espécie floresce de dezembro a maio, e frutifica de julho a agosto.
7.5. Mandevilla novocapitalis Markgr., Bradea 1(8): 49. 1971.

Fig. $4 b-d$

Subarbustos eretos, $10-40 \mathrm{~cm}$ alt. Ramos esparsamente pubescentes. Folhas opostas, às vezes verticiladas; pecíolos 2-3 $\mathrm{mm}$ compr., glabros; lâminas 4-7,5 × 1-3 cm, ovais, obovais, elípticas ou oblongas, cartáceas, ápice agudo a acuminado, base aguda a obtusa, face adaxial e abaxial glabra, coléteres ausentes; nervação broquidódroma. Inflorescências terminais, 4-12-flora; pedúnculo 5-10 cm compr.; brácteas 2-7,5 × 1-2,5 mm, lanceoladas, glabras. Flores 2,8-3,6 cm compr., róseas a avermelhadas com fauce amarela. Cálice com lacínias 8-11 × 1,5-3,5 mm, lanceoladas, coléteres contínuos. Corola sub-hipocrateriforme; tubo inferior 6-8,5 × 3-4 mm, cilíndrico; tubo superior 13-17 × ca. $4 \mathrm{~mm}$, cilíndrico, sulcado; lobos 19-21 mm compr., rombóide-oblíquos. Disco nectarífero 5-lobado ou livres 2, altenocarpelares. Ovário glabro. Frutos e sementes não observados e não descritos na literatura. Material examinado: São Roque de Minas, estrada de São Roque de Minas a Sacramento, 17.XI.2007, fl., R. Morokawa et al. 146 (UEC); guarita de Sacramento, 6.XII.1994, fl., $R$. Romero \& J.N. Nakajima 1446 (HUFU, UEC).

Distribui-se no DF, GO e MG em Cerrado (Sales 1993). No PNSC foi coletada em campo sujo e campo limpo, somente na região NO do parque. Espécie semelhante a $M$. pohliana e $M$. illustris, diferindo destas principalmente pela fauce da corola estreita e amarela. Coletado com flores de outubro a dezembro. Segundo Sales (1993), a espécie floresce de setembro a fevereiro, com frutos conhecidos para o mês de fevereiro.

7.6. Mandevilla pohliana (Stadelm.) A.H. Gentry, Ann. Missouri Bot. Gard. 71(4): 1079. 1985.

Subarbustos eretos, 0,2-1 m alt. Ramos pubescentes a velutino-tomentosos. Folhas opostas; pecíolos 1-4 mm compr., glabros; lâminas 4-8,6 $\times 1,8-4,5 \mathrm{~cm}$, elípticas, obovais, oblongas, ovais, cartáceas, ápice obtuso-mucronado, acuminado, base arredondada, face adaxial glabra a velutina, face abaxial glabra, esparso tomentosa, velutina; coléteres na base da face adaxial; nervação broquidódroma. Inflorescências terminais, 4-13-flora; pedúnculo 7,5-14 cm compr.; brácteas 4-7,5 mm compr., triangulares, esparso-tomentosas. Flores $4-7 \mathrm{~cm}$ compr., róseas com a fauce vermelho escuro; pedicelos 8-20 mm compr. Cálice com lacínias 7-7,5 $\times$ ca. $2 \mathrm{~mm}$, oval-lanceoladas, coléteres contínuos. Corola infudibuliforme; tubo inferior 9-10 × 2,5-4 $\mathrm{mm}$, cilíndrico; tubo superior 25-30 × 10-15 mm, cilíndrico, sulcada; lobos 18-20 mm compr., obovalorbiculares. Disco nectarífero 2 alternocarpelares. 


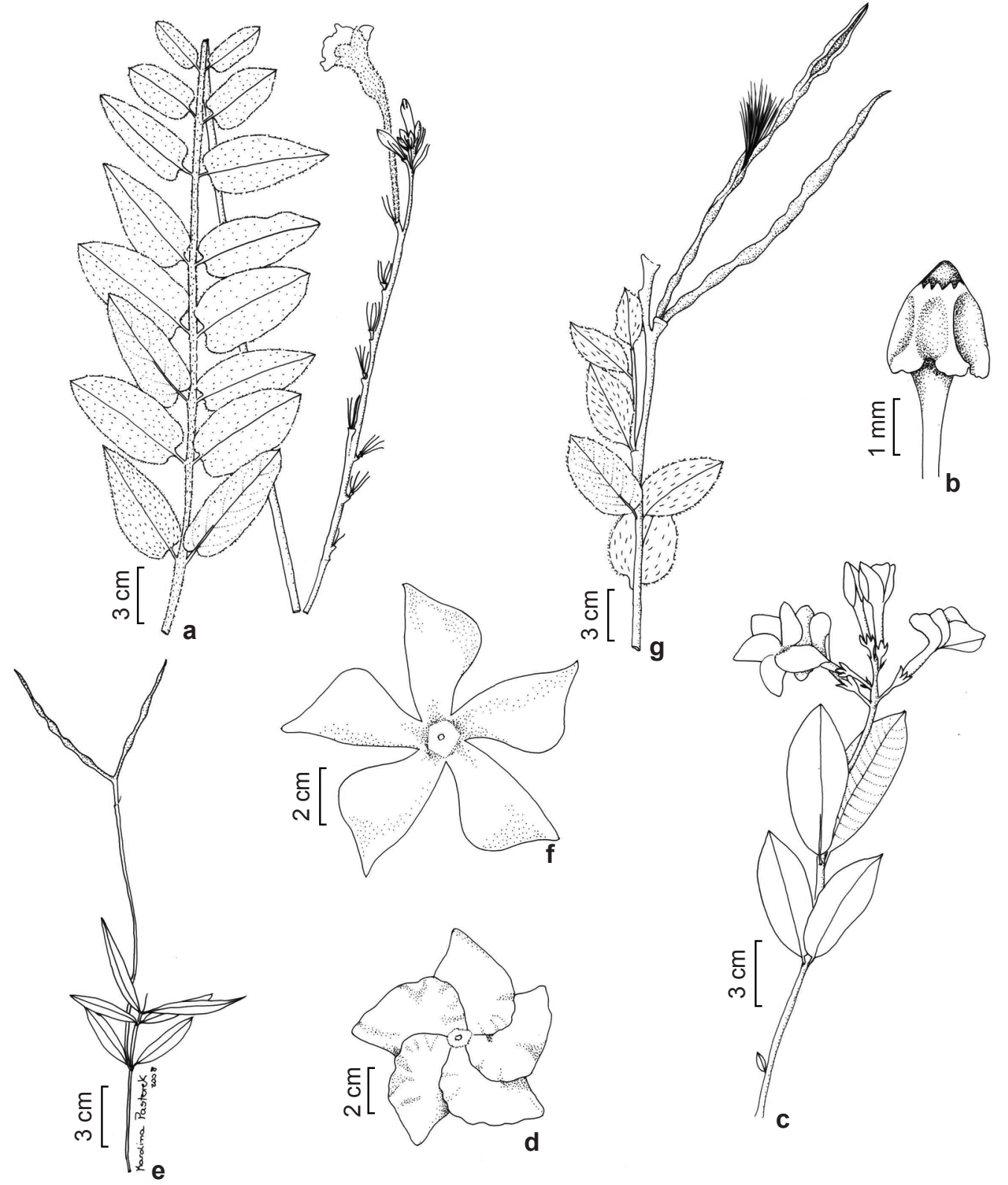

Figura 4 - a. Mandevilla martii (Müll. Arg.) Pichon - ramo florífero. b-d. M. novocapitalis Markgr. - b. cabeça do estilete; c. ramo florífero; d. flor em vista frontal. e-f. M. tenuifolia (J.C. Mikan) Woodson - e. ramo com frutos; f. flor em vista frontal. g. M. velame (A. St.-Hil.) Pichon - ramo com fruto (a Silva \& L.R. Reato 864; b-d Morokawa et al. 188; e Morokawa et al. 162; f Romero et al. 3887; g Souza 25344).

Figure 4 - a. Mandevilla martii (Müll. Arg.) Pichon - flowering branch. b-d. M. novocapitalis Markgr. - b. style head; c. flowering branch; d. flower in frontal view. e-f. M. tenuifolia (J.C. Mikan) Woodson - e. branch with fruit; f. flower in frontal view. g. M. velame (A. St.-Hil.) Pichon - branch with fruit (a Silva \& L.R. Reato 864; b-d Morokawa et al. 188; e Morokawa et al. 162; fomero et al. 3887; g Souza 25344).

Ovário glabro. Folículos $13-17 \times 0,2-0,3 \mathrm{~cm}$, cilíndricos, livres no ápice. Sementes não vistas.

Material selecionado: Capitólio, região da Represa de Furnas, 7.XII.2005, fl., R. Romero et al. 7339 (HUFU). Delfinópolis, Condomínio de Pedra, 28.XI.2003, fl., J.N.
Nakajima et al. 3747 (HUFU). São Roque de Minas, estrada de São Roque de Minas a Sacramento, 17.XI.2007, fl., R. Morokawa et al.136 (UEC).

Amplamente distribuída no Cerrado nas Regiões Centro-Oeste, Sudeste e Sul do Brasil 
e também na Bolívia, Paraguai e Argentina (Kinoshita et al. 2005). No PNSC foi coletada em campo rupestre, campo limpo, cerrado s. str., cerrado rupestre e em áreas de pastagem. Coletado com flores de novembro a fevereiro. Segundo Sales (1993), a espécie floresce de setembro a março, com frutificação estendendo-se até junho e julho.

7.7. Mandevilla tenuifolia (J.C. Mikan) Woodson, Ann. Missouri Bot. Gard. 20: 679. 1933.

Fig. $4 \mathrm{e}-\mathrm{f}$

Subarbustos eretos ou volúveis, $10-50 \mathrm{~cm}$ alt. Ramos pubescentes. Folhas opostas; pecíolo ca. 2 mm compr., glabras ou pilosas; lâminas 1,2-14,2 $\times$ 0,1-1,4 cm, estreito-oblongas, lineares a elípticas, membranácea a cartácea, ápice agudo a acuminado, base aguda, ambas as faces pubérulas, às vezes glabras, coléteres na base da face adaxial; nervação broquidódroma. Inflorescências axilares, terminais ou subterminais, 1-8-flora; pendúnculo 3-10 cm compr.; brácteas ca. $3,5 \mathrm{~mm}$ compr., lanceoladas, glabras a pubérulas. Flores ca. $2 \mathrm{~cm}$ compr., roxas, lilases, ou róseas, fauce branca e região central amarela; pedicelos 5-10 $\mathrm{mm}$ de compr. Cálice com lacínias 4-6×1-1,5 mm; coléteres alternos. Corola hipocrateriforme; tubo inferior 10-15 × 1,4-1,8 $\mathrm{mm}$, cilíndrico; tubo superior 4,1-5,3 $\times 2,6-2,8$ $\mathrm{mm}$, cilíndrico; lobos 1-1,45 cm compr., obvaloblíquos. Disco nectarífero 2 alternocapelares. Ovário glabro. Folículos 6,3-7,2 × 0,1-0,2 cm, cilíndricos, levemente torulosos. Sementes ca. 0,3 cm compr.; coma ca. $0,8 \mathrm{~cm}$ compr.

Material selecionado: Capitólio, região da Represa de Furnas, Cachoeira Feixo da Serra, 24.X.2006, fl., R. Romero et al. 7859 (HUFU). Delfinópolis, Fazenda Zé Antunes, 13.IV.2002, fl., R.L. Volpi et al. 116 (HUFU). São Roque de Minas, trilha do Vão dos Cândidos para a Garagem de Pedras, 21.XII.2007, fl., R. Morokawa et al. 184 (UEC).

Amplamente distribuída no Brasil, do Pará a São Paulo, alcançando o planalto das Guianas no Suriname; em afloramentos rochosos (Sales \& Kinoshita 2005). No PNSC foi coletada em campo rupestre, campo limpo, cerrado rupestre, cerrado s. str. Mandevilla tenuifolia é polimórfica, apresentando variação nas cores das flores e na forma das folhas, algumas possuem aspecto de roseta com as folhas congestas na base dos ramos e flores róseas quase brancas com manchas lilases, enquanto outras apresentam as folhas distribuídas regularmente ao longo dos ramos e flores em tom róseo ou lilás. O hábito também pode se mostrar bastante variável, com plantas eretas ou volúveis. Coletado com flores de outubro a março, e com frutos de janeiro a abril. Segundo Sales (1993), a espécie floresce de novembro a março, e o de frutificação se estende de dezembro a maio.

7.8. Mandevilla velame (A. St.-Hil.) Pichon, Bull. Mus. Natl. Hist. Nat., sér. 2, 20: 107. 1948.

Fig. $4 \mathrm{~g}$

Subarbustos eretos, 0,4-0,6 m alt. Ramos albo-lanosos. Folhas opostas; pecíolos $0,2-0,8$ cm compr., lanosos; lâminas $(2,5) 3,1-5,2 \times$ $1,2-2,8 \mathrm{~cm}$, oblongas, elípticas, ovais, cartáceas, ápice acuminado, mucronado, base arredondada, ambas as faces albo-lanosas, coléteres na base da face adaxial; nervação broquidódroma. Inflorescências terminais, 1-6-flora; pedúnculo 3-9 cm compr.; brácteas ca. $1 \mathrm{~cm}$ compr., filiformes, albo-lanosas. Flores $12-14 \mathrm{~cm}$ compr., branco-esverdeadas com fauce amarela; pedicelos 2,5-4 mm compr. Cálice com lacínias 15-30 × 1,6-2,3 mm, lanceoladas, coléteres contínuos. Corola hipocrateriforme; tubo inferior 70-90 $\times 2-4 \mathrm{~mm}$, cilíndrico; tubo superior 20-30 $\times$ 8-12 mm, cilíndrico; lobos 18-40 mm compr., obovais. Disco nectarífero 3-5 lobado. Ovário glabro. Folículos $16-26 \times 0,4-0,6 \mathrm{~cm}$, torulosos, livres no ápice, tomentosos. Sementes 9-11 $\times$ 2-3 mm; coma 1,6-2,7 cm compr.

Material selecionado: Capitólio, estrada FurnasCapitólio, 13.II.1998, f1., R. Romero et al. 5159 (UEC). São Roque de Minas, 12.I.1994, A.M. Giulietti et al. (ESA23093); Retiro de Pedra, 21.III.1996, fl., J.K. Nakajima \& R. Romero 1673 (HUFU, UEC).

Material adicional: BRASIL. SÃO PAULO: Itú, Área de Proteção Ambiental, 17.IV.1987, W.S. Souza 25344 (UEC).

Distribui-se no Brasil (DF, GO, MG, SP e RS) e Uruguai, em cerrado aberto e ocasionalmente em mata ciliar (Barban 1985). No PNSC foi coletada em campo rupestre, campo limpo e cerrado s. str. Coletado com flores de novembro a março, e com frutos em julho. Segundo Kinoshita et al. (2005), a espécie floresce de outubro a abril, e frutifica de janeiro a junho.

8. Mesechites mansoanus (A. DC.) Woodson, Ann. Missouri Bot. Gard. 20(4): 636-637.1933.

Fig. 5a-b

Lianas; látex branco. Ramos glabros a pubérulos, coléteres nodais presentes; estípulas ausentes. Folhas opostas; pecíolos $0,9-1,8 \mathrm{~cm}$ compr., pubérulos; lâminas 5,6-11 × 2-4,5 cm, elípticas, subcoriáceas, ápice obtuso a acuminado, base aguda a obtusa, ambas as faces glabras; 2-4 coléteres deltóides geralmente bilobados 

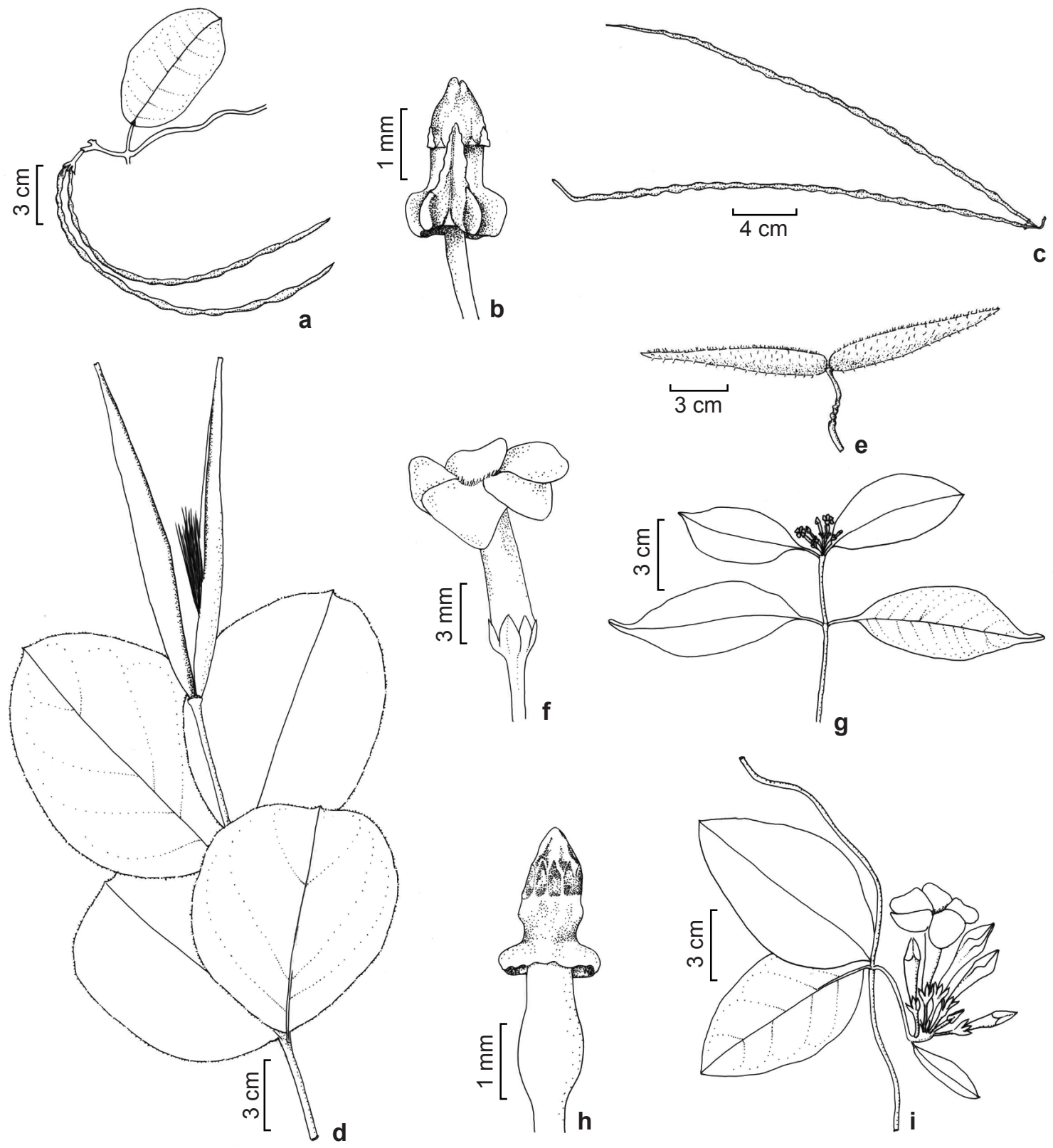

Figura 5 - a-b. Mesechites mansoanus (Vell.) A. DC. - a. ramo com frutos; b. cabeça do estilete. c. Prestonia coalita (Vell.) Woodson - frutos. d. P. erecta (Malme) J.F. Morales - ramo com fruto. e. P. tomentosa R. Br. - fruto. f-g. Secondatia densiflora A. DC. - f. flor em vista lateral; g. ramo florífero. h-i. Temnadenia violacea (Vell.) Miers - h. cabeça do estilete; i. ramo florífero. (a-b Bernarcci et al. 1857; c A.O. Simões et al. 149; d Simões et al. 1200; e Castellani et al. 161; f-g Kinoshita et al. 02/106; h-i Simões et al. 69).

Figure 5 - a-b. Mesechites mansoanus (Vell.) A. DC. - a. branch with fruit; b. style head. c. Prestonia coalita (Vell.) Woodson - fruits. d. P. erecta (Malme) J.F. Morales - branch with fruit. e. P. tomentosa R. Br. - fruit. f-g. Secondatia densiflora A. DC. - f.; flower in lateral view; g. flowering branch. h-i. Temnadenia violacea (Vell.) Miers - h. style head; i. flowering branch. (a-b Bernarcci et al. 1857; c A.O. Simões et al. 149; d Simões et al. 1200; e Castellani et al. 161; f-g Kinoshita et al. 02/106; h-i Simões et al. 69). 
na base da nervura central e ápice do pecíolo; domácias ausentes; nervação broquidódroma. Inflorescências axilares, 12-16-flora; pedúnculo 0,5-2,5 cm compr.; brácteas ca. $1 \mathrm{~mm}$ compr., amplamente ovais, glabras. Flores 2,5-2,7 cm compr., branco-esverdeadas; pedicelos 6-8 $\mathrm{mm}$ compr., retos. Cálice com lacínias 3,1-3,4 × 2-2,5 $\mathrm{mm}$, iguais, ovais, coléteres contínuos. Corola com tubo inferior $12,4-17 \times 2,4-2,8 \mathrm{~mm}$; tubo superior $8,7-11 \times 3,8-4,0 \mathrm{~mm}$; lobos $6,8-7,8$ $\mathrm{mm}$ compr., oval-oblíquos. Anteras apiculadas, glabras. Cabeça do estilete com 5 projeções longitudinais restritas a base. Disco nectarífero 5 lobado. Folículos (12-)18-23 × 0,3-0,4 cm, torulosos, lenticelados. Sementes 5-8 $\times$ ca. $1 \mathrm{~mm}$; coma 1,9-3,1 cm compr.

Material examinado: Delfinópolis, 9.I.1996, fl., V.C. Souza et al. 9885 (ESA). São Roque de Minas, estrada de Vargem Bonita a São Roque de Minas, 20.XII.2007, fl., $R$. Morokawa et al. 171 (UEC).

Material adicional: BRASIL. SÃO PAULO: Valentim Gentil, 18.V.1995, fr., Bernarcci et al. 1857 (UEC).

Distribui-se no sudeste do Brasil chegando ao Oeste da Bolívia e Paraguai em áreas de cerrado, campo cerrado e campo rupestre (Kinoshita et al. 2005). No PNSC foi coletada em borda de mata seca semidecídua e campo rupestre. Espécie reconhecida em campo pelas folhas que apresentam coléteres triangulares na base da lâmina e ápice do pecíolo, geralmente com margem da lâmina avermelhada, sendo que em exsicatas essa margem se apresenta mais clara. Coletado com flores em dezembro e janeiro. Segundo Morales (2006), a espécie floresce de outubro a maio, e são conhecidos espécimes com frutos para os meses de abril a junho, e outubro a dezembro.

9. Odontadenia lutea (Vell.) Markgr., Repert. Spec. Nov. Regni Veg. 20: 24. 1924.

Lianas; látex branco. Ramos pubescentes; coléteres nodais presentes; estípula interpeciolar lanceolada ou bilobada, 1-5 mm compr., caduca. Folhas opostas; pecíolos 3-7 mm compr., pilosos; lâminas (5-)7,5-16,5 × 3-8 cm, oblongas a ovais, cartáceas a subcoriáceas, ápice cuspidado a acuminado, base obtusa a cordada, ambas as faces pilosas com aspecto aveludado; domácias ausentes; nervação boquidódroma. Inflorescências axilares ou terminais, tirsiformes, 6-6-flora; pendúnculo 0,5-3 cm compr.; brácteas 3-7 mm compr., ovais, glabras. Flores 4,5-7 cm compr., brancoamareladas; pedicelos $1-2,1 \mathrm{~cm}$ compr., retos. Cálice com lacínias 6-13 × 5-9 mm, desiguais, coléteres irregularmente distribuídos. Corola infundibuliforme; tubo inferior 20-23 $\times$ 4-8 mm, cilíndrico; tubo superior 18-23 $\times 18-2 \mathrm{~mm}$ compr., infundibuliforme; lobos 18-25 mm compr., obovaloblíquos. Anteras 7-8 mm compr. Disco nectarífero inteiro. Ovário glabro. Folículos 8,5-10 × 1,4-1,8 $\mathrm{cm}$, cilíndricos, levemente achatados lateralmente, lisos com regiões rugosas, pubescentes a glabros. Sementes 8-9 × 2-3 mm; coma 3-4 cm compr. Material selecionado: Capitólio: região da Represa de Furnas, Paraíso Perdido, 16.II.2006, fl., R. Romero et al. 7605 (HUFU, UEC). Delfinópolis: trilha Escada de Pedra, fl. e fr., $R$. Romero et al. 6886 (HUFU). São Roque de Minas, parte de cima da Casca d'anta, 12.XII.1996, fl., W. Marcondes-Ferreira et al. 1431 (UEC).

Distribui-se no NO da Bolívia, oeste do Peru (Morales 1999a) e Brasil (MT, MG, PA, RJ e SP), em ambientes de campo e cerrado (Kinoshita et al. 2005) e Goiás. No PNSC foi coleta em campo rupestre, cerrado s. str. e cerrado rupestre. Espécie reconhecida pelas estípulas interpeciolares e flores alvas. Coletado com flores de dezembro a julho, e com frutos de março a julho. Segundo Morales (1999a), a espécie floresce de fevereiro a novembro, e frutifica de março a outubro.

10. Peltastes peltatus (Vell.) Woodson, Ann. Missouri Bot. Gard. 19(4): 376. 1932.

Lianas; látex incolor. Ramos ferrugíneopubescentes quando jovens, glabros quando adultos; coléteres nodais intrapeciolares e interpeciolares em ramos jovens; estípulas ausentes. Folhas opostas, peltadas; pecíolos 2,4-4,6 cm compr., ferrugíneopubescentes; lâminas 10,3-14,2 × 7-11 cm, suborbiculares a elíptica-obovais, membranáceas a cartáceas, ápice acuminado, base arredondada, face adaxial e abaxial pubérulas; domácias ausentes; nervação boquidródoma. Inflorescências axilares, 1-4-flora; pedúnculo 0,5-1,5 cm compr.; brácteas $12-17 \mathrm{~mm}$ compr., elipticas, glabras. Flores 5,8-7 cm compr.; pedicelos 20-29 mm compr., retos. Cálice com lacínias 18-25 × 7-11 mm, iguais, oblongo-elípticas, coléteres opostos. Corola com tubo superior $21 \times 18 \mathrm{~mm}$, cônico-campanulado; tubo inferior 20-25 × 8-12 mm cilíndrico; lobos 30-31 mm compr., elíptico-oblongos. Disco nectarífero 5 lobado. Ovário piloso. Folículos 19,5 $\times 1,7 \mathrm{~cm}$, lenhosos, falcados, unidos no ápice, ferrugíneo-pubescentes. Sementes $1,1 \times 0,4 \mathrm{~cm}$; coma 4,4-5,4 cm compr.

Material examinado: São Roque de Minas, Retiro de Pedras, 13.X.2007, fl., R. Morokawa et al. 117 (UEC); Retiro de Pedras, 16.XI.2007, fr., R. Morokawa et al. 128 (UEC). 
Distribui-se na Argentina, Paraguai e Brasil (DF, MG, RJ e SP) em matas (Kinoshita et al. 2005). No PNSC foi coletada em borda de mata seca semidecídua. Coletado com flores em outubro, e com frutos em novembro. Segundo Morales (2005b), a espécie floresce de setembro a dezembro, e exemplares com frutos foram coletados entre fevereiro e maio.

11. Prestonia R. Br., Asclepiadeae: 58. 1810, nom. cons.

Lianas ou subarbustos; látex incolor. Coléteres nodais presentes; estípulas ausentes.
Folhas opostas, coléteres ausentes, domácias ausentes, nervação broquidódroma. Cálice com lacínias iguais, com um único coléter oposto ou alterno. Corola hipocrateriforme; fauce com anel caloso conspícuo ou incospícuo. Estames inclusos a exclusos; apêndices supraestaminais presentes ou ausentes. Cabeça do estilete fusiforme com espessamento basal. Cápsulas septicidas ou folículos 2. Gênero neotropical, com cerca de 60 espécies. Ocorre desde as Antilhas até o sul do Brasil e norte da Argentina, em matas, cerrados e mais raramente em restingas (Kinoshita et al. 2005).

\section{Chave de identificação para as espécies de Prestonia}

1. Subarbustos eretos

1'. Lianas

2. Corola com apêndices supraestaminais; frutos napiformes

11.4. P. tomentosa

2'. Corola sem apêndices supraestaminais; frutos cilíndricos a moniliformes 3

3. Fauce da corola com anel carnoso conspícuo; lobos da corola reflexos ....... 11.3. P. riedelii

3'. Fauce da corola sem anel carnoso inconspícuo; lobos da corola patentes .... 11.1. P. coalita

11.1. Prestonia coalita (Vell.) Woodson, Ann. Missouri Bot. Gard. 18: 552. $1931 . \quad$ Fig. 5c Lianas. Ramos jovens pubérulos, adultos glabros. Pecíolos 0,5-1,3 cm compr., pubescentes; lâminas 7,5-13 × 2,5-4 cm, elípticas, membranáceas, ápice agudo a acuminado, base aguda a cuneada, face adaxial pilosa somente nas nervuras, face abaxial estrigosa. Inflorescências axilares, umbeliformes, 5-16-flora; pedúnculo $0,2-0,5 \mathrm{~cm}$ compr.; brácteas $2-2,5 \mathrm{~mm}$ compr., deltóides a lanceoladas, pubérulas. Flores ca. 1,5 cm compr., amarelo a amarelo-esverdeadas; pedicelos 8-9 mm compr., retos. Cálice com lacínias 3,8-5 × 0,7-1,2 $\mathrm{mm}$, lanceoladas, coléteres contínuos. Corola sem apêndices supraestaminais; fauce com anel caloso inconspícuo, não carnoso; tubo inferior $7 \times 4,3 \mathrm{~mm}$, cilíndrico a urceolado; tubo superior ca. $6 \times 3,5 \mathrm{~mm}$, cilíndrico; lobos 5,3 ×6 mm compr., oblíquo-obovais, patentes. Estames exclusos; anteras glabras. Disco nectarífero 5-lobado. Ovário glabro. Cápsulas septicidas $16,5-47 \times 0,3-0,5 \mathrm{~cm}$, moniliformes. Sementes $0,7-1,1 \times 0,1-0,2 \mathrm{~cm}$; coma $1,7-2,6$ cm compr.

Material examinado: Delfinópolis, Vale da Babilônia, Pousada Babilônia, 8.XII.2008, fl., M.F. Silveira et al. 42 (UEC). São Roque de Minas, Vão dos Cândidos, Fazenda das Posses, 21.XII.2007, fl., R. Morokawa et al. 182 (UEC).
Material adicional: BRASIL. MINAS GERAIS: Carrancas, Vargem Grande, 22.VI.1998, fr., A.O. Simões et al. 179 (UEC).

Amplamente distribuída no Brasil (AC, AM, BA, CE, GO, MA, MT, PB, PE e na Regiões Sudeste e Sul), e no NO da Argentina e Paraguai. Ocorre em borda de mata, em formações de cerrado, caatinga e mais raramente em restinga (Rio \& Kinoshita 2005). No PNSC foi coletada em mata seca semidecídua. É reconhecida pelas lacínias do cálice escariosas. Coletado com flores em dezembro. Segundo Simões \& Kinoshita (2002), a espécie floresce de dezembro a março, com frutos coletados em janeiro e fevereiro.

11.2. Prestonia erecta (Malme) J.F. Morales, Novon 9: 90. 1999.

Fig. $5 \mathrm{~d}$

Subarbustos 0,3-0,6 m alt.. Pecíolos 0,3-0,8 cm compr., pubescentes; lâminas 5,5-12,5 × $6,5-12,5 \mathrm{~cm}$, oblongas, ovais a orbiculares, subcoriáceas, ápice agudo a acuminado, mucronado, base atenuada, face adaxial esparsamente pilosa a tomentosa, face abaxial tomentosa. Inflorescências terminal, cimosa, 2-16-flora; pedúnculo 2-4,5 cm compr.; brácteas, $0,9-1,5 \mathrm{~cm}$, oval-oblongas, glabras. Flores 1,7-2,0 cm compr.; pedicelos 10-20 mm compr., retos. Cálice com lacínias 16-27 × 7-17 $\mathrm{mm}$, ovais a oblongas, coléteres alternos. Corola sem 
apêndices supra-estaminais, fauce com anel caloso conspícuo, amarelo, carnoso; tubo inferior ca. 11 $\times 2,8-4,5 \mathrm{~mm}$, cilíndrico; tubo superior 6,5-7,5 $\times 2,5-3,7 \mathrm{~mm}$, cilíndrico; lobos 8-11 mm compr., oblíquo-ovais, patentes. Anteras glabras. Ovário glabro. Folículos $14-15 \times 0,7-1,3 \mathrm{~cm}$. Sementes $0,9-1,2 \times 0,2-0,4 \mathrm{~cm}$, coma $8-8,5 \mathrm{~cm}$ compr.

Material selecionado: Capitólio, região da Represa de Furnas, 25.X.2006, fl., J.N. Nakajima et al. 4213 (HUFU). Delfinópolis, Vale da Babilônia, Cachoeira Tamanduá, 10.XII.2008, fl., M.F. Silveira et al. 96 (UEC). São Roque de Minas, estrada de São Roque de Minas a Vargem Bonita, 20.XII.2007, fl., R. Morokawa et al. 170 (UEC).

Amplamente distribuída no Brasil, e SE da Bolívia e NE do Paraguai (Morales 1999b). Esse trabalho segue a proposta de Morales (1999b) que inclui o gênero monotípico Rhodocalyx como sinônimo de Prestonia devido às similaridades morfológicas encontradas, como anel caloso na fauce, ausência de coléteres laminares. O estudo filogenético molecular para a subfamília Apocynoideae (Livshultz et al. 2007) indica que Prestonia não é um gênero monofilético e que esta fortemente relacionado com Rhodocalyx. No entanto, é necessário um estudo filogenético com uma amostragem maior para o gênero. No PNSC foi coletada em campo rupestre, cerrado rupestre, cerrado $s$. str. e em ambiente antropizado. Prestonia erecta é reconhecível pelas flores vináceas e fauce com anel carnoso e amarelo. Coletado com flores de outubro a dezembro, e com frutos em dezembro. Segundo Simões \& Kinoshita (2002), a espécie floresce de outubro a fevereiro, e frutifica de janeiro a fevereiro.

11.3. Prestonia riedelii (Müll. Arg.) Markgr., Feddes Repert. Spec. Nov. Regni Veg. 20: 26. 1924.

Lianas. Ramos pubescentes. Pecíolos 0,8-2 cm compr., pubescentes; lâminas 7-14 × 3,8-10,1 $\mathrm{cm}$, suborbiculares, elípticas, membranáceas, ápice agudo a acuminado, base obtusa a arredondada, face adaxial pubérula, face abaxial pubescente. Inflorescências axilares, racemosas, 6-23 flora; pedúnculo 1,4-2,4 cm compr.; brácteas 4-6 mm compr., oblongo-lanceoladas, pubescentes. Flores 1,5-1,7 cm compr., amarelo a amarelo-esverdeadas; pedicelos 10-22 mm compr., retos. Cálice com lacínias 11-14 × 5-6 mm, elípticas, coléteres continuos. Corola sem apêndices supra-estaminais; fauce com anel caloso conspícuo, carnoso; tubo 13-15 × 4-5 mm, cilíndrico, mais anguloso abaixo da inserção dos estames, acima lobado, torcido para a direita; lobos 13-15 mm compr., oblongo-elípticos, reflexos. Estames inclusos; anteras pilosas no terço superior da face abaxial. Ovário glabro. Disco nectarífero 5-lobado. Folículos 17-22 × 0,5-1 cm, cilíndricos a levemente moniliformes, pubérulos. Sementes 1,1-1,3 × 0,2 cm; coma 3,5-4 cm compr. Material examinado: Delfinópolis, Vale da Babilônia, Pousada Babilônia, 8.XII.2008, fl. e fr., M.F. Silveira et al. 60 (UEC). São João Batista do Glória, estrada para cachoeira da Pousada Mata do Engenho, 6.XI.2008, fl., L.S. Kinoshita et al. 08-317 (UEC).

Distribui-se no Brasil (Regiões Sul e Sudeste), Peru, Bolívia, Paraguai e norte da Argentina em floresta estacional semidecídua, regiões degradadas e matas ciliares (Rio \& Kinoshita 2005). No PNSC foi coletada em mata ciliar. Espécie semelhante a $P$. tomentosa diferindo desta pelos lobos das pétalas reflexos e anel da fauce amarelo. Coletado com flores em novembro e dezembro, e com frutos em dezembro. Segundo Kinoshita et al. (2005), a espécie floresce de outubro a fevereiro e frutifica de abril a julho.

11.4. Prestonia tomentosa $\mathrm{R}$. Br., Mem. Wern. Nat. Hist. Soc. 1:70. 1811.

Fig. 5e

Lianas. Ramos ferrugíneo-tomentosos. Pecíolos 0,5-1 cm compr., tomentosos; lâminas 9,5-16,5 × 4,5-13,5 cm, amplamente ovais, elípticas a amplamente elípticas, cartáceas, ápice acuminado, base obtusa a arredondada, face adaxial pubescente, face abaxial densamente ferrugíneotomentosa. Inflorescências axilares, umbeliformes, 9-15-flora; pedúnculo 1,3-2,5 cm compr.; brácteas 10-14 mm compr., lanceoladas, tomentosas. Flores 1,5-2 cm compr., amarelas tornando-se mais escura em direção à fauce; pedicelos ca. 8 $\mathrm{mm}$ compr., retos. Cálice com lacínias 14-18 × 7-10 mm, ovais a oblongas, coléteres contínuos. Corola com apêndices supra-estaminais, fauce com anel caloso conspícuo, branco, carnoso; tubo $17-18 \times 7-8 \mathrm{~mm}$, não abaulado na base; lobos 12-14 mm compr., orbicular-oblíquos, patentes. Estames parcialmente exclusos. Ovário glabro. Disco nectarífero 5-lobado. Folículos 5,5-10 × $1,2-1,8 \mathrm{~cm}$, napiformes, densamente ferrugíneotomentosos, glabrescentes. Sementes $0,7-1,6 \times$ 0,2-0,3 cm; coma 2,3-3,3 cm compr.

Material examinado: Delfinópolis, Vale da Babilônia, 9.XII.2008, fl., M.F. Silveira et al. 73 (UEC). São Roque de Minas, distrito de São José do Barreiro, Pousada Recanto da Canastra, 18.XI.2007, fl., R. Morokawa et al. 152 (UEC). Material adicional: BRASIL. MINAS GERAIS: Barretos, Ribeirão Anhumas, 18.III.1997, fr. E.D. Castellani et al. 161 (UEC). 
Amplamente distribuída, ocorre desde a Colômbia e Venezuela até Bolívia, Brasil (AC, AM, PB, PR, RO e Região sudeste), NE da Argentina e Paraguai. Encontrada em borda de floresta semidecídua, mata ciliar, cerradão, cerrado e áreas de restinga (Rio \& Kinoshita 2005). No PNSC foi coletada em mata ciliar, é semelhante a $P$. riedelii, diferindo desta por apresentar lobos da corola patentes e anel da fauce branco. Coletado com flores em novembro e dezembro. Segundo Simões \& Kinoshita (2002), a espécie floresce de setembro a março, e frutifica de março a agosto.

12. Secondatia densiflora A. DC., Prodr. 8: 445. 1844.

Fig. $5 \mathrm{f}-\mathrm{g}$

Lianas; látex branco. Ramos glabros; coléteres nodais intrapeciolares; estípulas ausentes. Folhas opostas; pecíolos $0,9-1,3 \mathrm{~cm}$ compr., glabros; lâminas 7,3-10 × 3-5 cm, elípticas, ápice acuminado a cuspidado, base obtusa a arredondada, ambas as faces glabras. Inflorescências terminais, tirsóides, 13-24-flora; pedúnculo 1,4-2 cm compr.; brácteas $17-25 \mathrm{~mm}$ compr, ovais, glabras. Flores 8-11 cm compr., brancas; pedicelos ca. 3,5 mm compr., retos. Cálice com lacínias 1,8-2,7 × 1,2-1,4 $\mathrm{mm}$, iguais, ovais, coléteres alternos. Corola hipocrateriforme; tubo 7,3-8,2 × 1,8-2,0 mm; lobos ca. $4 \mathrm{~mm}$ compr., obliquamente oval-triangulares. Anteras oblongo-lineares, sagitadas, abaxialmente tomentosas, apiculadas. Ovário glabro. Disco nectarífero 5-lobado. Folículos 14,5-15,5 × 2,4-3 $\mathrm{cm}$, lenhosos, pendentes, glabros. Sementes $2 \mathrm{~cm}$ compr., elípticas, curtamente rostradas; coma ca. $4,8 \mathrm{~cm}$ compr.

Material examinado: Capitólio, Região da Represa de Furnas, 13.VII.2006, fl., A.A. Arantes et al. 2006 (HUFU, UEC). São João Batista do Glória, Mata do Engenho, 4.IX.2008, fl. e fr., R. Morokawa et al. 223 (UEC).

Material adicional: BRASIL. MINAS GERAIS: Santana do Riacho, distrito de Cardeal Mota, 24.IX.2002, fl., L.S. Kinoshita et al. 02-106 (UEC).

Distribui-se do norte da Colombia e leste da Venezuela até o Brasil, Bolívia e Paraguai em várias formações vegetacionais, é a espécie mais comum e com maior distribuição entre as espécies do gênero (Morales 2003). No PNSC foi coletada em mata ciliar. Espécie reconhecida no campo por apresentar fauce pilosa, e pelos frutos lenhosos, divergentes e pendentes. Coletado com flores em julho e setembro, e com frutos em setembro. Segundo Koch \& Kinoshita (1999), a espécie floresce de setembro a novembro, e pode ser encontrada com frutos principalmente em abril.
13. Temnadenia violacea (Vell.) Miers, Apocyn. S. Amer.: 208. 1878.

Fig. 5h-i

Lianas; látex incolor. Ramos adultos glabros, com escamas finas esbranquiçadas, jovens hirsutos; coléteres nodais intrapeciolares; estípulas ausentes. Pecíolos 0,3-0,5 cm compr., hirsutos; lâminas 5,7-11 $\times 2,5-5,9 \mathrm{~cm}$, elípticas, ovais a estreitamente ovais, membranáceas, face adaxial pubérula, face abaxial pubérula com nervuras pubescentes; domácias ausentes; nervação broquidódroma. Inflorescências axilares, bostricóides, 7-9-flora; pendúnculo 3-4 mm compr.; brácteas $2-4 \mathrm{~mm}$ compr., filiformes, glabras. Flores ca. $6 \mathrm{~cm}$ compr., violáceas, com fauce e tubo interno esverdeado; pedicelos 10-15 mm compr., torcidos. Cálice com lacínias 8-9,2 × 3,6-5 $\mathrm{mm}$, oval-lanceoladas, coléteres alternos. Corola infudibuliforme; tubo inferior constrito 1,3-1,5 × 0,6 $\mathrm{mm}$, triangular, tubo superior 2-2,5 $\times 1,5-1,8 \mathrm{~mm}$ obtriangular; lobos 27-30 mm compr., oval-oblíquos. Disco nectarífero 5-lobado. Ovário glabro. Cápsulas septicidas $12-17,5 \times 0,4-0,5 \mathrm{~cm}$, glabras. Sementes $1,1-1,5 \times 0,1-0,2 \mathrm{~cm}$; coma $0,3-0,5 \mathrm{~cm}$ compr.

Material examinado: São Roque de Minas, trilha Casca d'Anta, 22.XII.2007, fl., R. Morokawa et al., 187 (UEC). Material adicional: BRASIL. MINAS GERAIS: Carrancas, Fazenda Grão-Mogol, 8.I.1998, fl., A.O. Simões et al. 69 (UEC); Serra do Moleque, 2.II.1998, fr., A.O. Simões et al. 109 (UEC).

Temnadenia violacea é endêmica do Brasil (BA, CE, GO, ES, MA, MT, MG, PR, PE e SP (Kinoshita et al. 2005). No PNSC foi coletada em campo rupestre próximo à mata. Coletado com flores em dezembro. Segundo Morales (2005c), a espécie floresce de outubro a maio, e frutifica de fevereiro a outubro.

\section{Agradecimentos}

Aos coodenadores do Projeto Flora da Serra da Canastra, Jimi Nakajima e Rosana Romero, da Universidade Federal de Uberlândia, por nos disponibilizar a coleção de Apocynaceae s.str. para o presente estudo. Ao CNPq, a bolsa de mestrado concedida à primeira autora. Ao IBAMA, a autorização de coleta. Aos curadores dos herbários consultados. À Anna Pastorek, as ilustrações.

\section{Referências}

Barban, J.R. 1985. Revisão taxonômica do gênero Macrosiphonia Muell.-Arg. (Apocynaceae). Dissertação de Mestrado. Universidade Estadual de Campinas, Campinas. 142p.

Endress, M.E. 2004. Apocynaceae: brown and now. Telopea 10: $525-541$. 
Endress, M.E. \& Bruyns, P.V. 2000. A revised classification of the Apocynaceae s.l. Botanical Review 66: 1-56.

Fallen, M.E. 1983. A taxonomic revision of Condylocarpon (Apocynaceae). Annals of the Missouri Botanical Garden 70: 149-169.

Farinaccio, M.A. \& Mello-Silva, R. 2004. Asclepiadoideae (Apocynaceae) do Parque Nacional da Serra da Canastra, Minas Gerais, Brasil. Boletim de Botânica da Universidade de São Paulo 22: 53-92.

Hansen, B.F. 1985. A monografic revision of Forsteronia. Tese de Doutorado. University of South Florida. 382p.

Hickey, L.J. 1973. Classification of the architecture of dicotyledonous leaves. American Journal of Botany. 60: 17-33.

IBAMA - Instituto Brasileiro do Meio Ambiente e dos Recursos Naturais Renováveis. 2005. Plano de manejo: resumo executivo do Parque Nacional da Serra da Canastra. MMA/IBAMA. 94p.

IBDF - Instituto Brasileiro de Desenvolvimento Florestal. 1981. Plano de Manejo. Parque Nacional da Serra da Canastra. IBDF, Brasília. 96p.

Judd, W.S.; Sanders, R.W. \& Donoghue, M.J. 1994. Angiosperm family pairs: preliminary phylogenetic analysis. Harvard Papers in Botany 5: 1-51.

Kinoshita, L.S.; Marcondes-Ferreira, W.; Rio, M.C.; Sales, M.F. \& Simões, A.O. 2005. Apocynaceae. In: Wanderley, M.G.L.; Shepherd, G.J.; Melhem, T.S.; Martins, S.E.; Kirizawa, M. \& Giulietti, A.M. (eds.). Flora fanerogâmica do estado de São Paulo. Vol. 4. RiMa, São Paulo. Pp. 35-91.

Leeuwenberg, A.J.M. 1994. A revision of Tabernaemontana: the new world species and Stemnadenia. Vol. 2. Royal Botanic Gardens, Kew. Pp. 213-450.

Livshultz, T.; Middleton, D.J.; Endress, M.E \& Williams, J.K. 2007. Phylogeny of Apocynoideae and the APSA clade (Apocynaceae s.l.). Annals of the Missouri Botanical Garden 94: 324-359.

Koch, I. \& Kinoshita, L.S. 1999. As Apocynaceae s.str. da região de Bauru, São Paulo, Brasil. Acta Botanica Brasilica 13: 61-86.

Morales, J.F. 1999a. A synopsis of the genus Odontadenia: series of revisions of Apocynaceae XLV. Bulletin du Jardin Botanique National de Belgique 67: 381-477.

Morales, J.F. 1999b. Rhodocalyx (Apocynaceae), a new synonym of Prestonia. Novon 9: 89-91.

Morales, J.F. 2003. Studies in neotropical Apocynaceae III: a revision of the genus Secondatia A. DC., with discussion of its generic classification. Candollea 58: 305-319.

Morales, J.F. 2005a. Estudios en las Apocynaceae neotropicales XIX: la família Apocynaceae s.str. (Apocynoideae, Rauvolfioideae) de Costa Rica. Darwiniana 43: 90-191.

Morales, J.F. 2005b. Estudios en las Apocynaceae neotropicales XX: monografia del género Peltastes
(Apocynaceae, Echiteae), con uma sinopsis de Stipecoma. Candollea 60: 289-334.

Morales, J.F. 2005c. Estudios en las Apocynaceae neotropicales XIII: revisión del género Temnadenia (Apocynaceae, Echiteae). Candollea 60: 207-231.

Morales, J.F. 2006. Estudios en las Apocynaceae neotropicales XXIV: uma monografia del género Mesechites (Apocynaceae, Mesechiteae). Candollea 61: 215-277.

Radford, A.E.; Dickison, W.C.; Massey, J.R. \& Bell, C.R. 1974. Vascular plant systematics. Harper \& Row, New York.

Rapini, A.; Koch, I.; Kinoshita, L.S.; Simões, A.O. \& Spina, A.P. 2010. Apocynaceae. In: Forzza, R.C. et al. (eds.). Lista de espécies da flora do Brasil. Jardim Botânico do Rio de Janeiro. Disponível em <http://floradobrasil. jbrj.gov.br/2010/FB000048>. Acesso em 17 Out 2011.

Ribeiro, J.F. \& Walter, B.M.T. 1998. Fitofisionomias do bioma cerrado. In: Sano, S.M. \& Almeida, S.P. (eds.). Cerrado: ambiente e flora. EMBRAPA-CPAC, Planaltina. Pp. 89-166.

Rio, M.C.S. \& Kinoshita, L.S. 2005. Prestonia (Apocynaceae) no Sul do Brasil. Hoehnea 32: 233-258.

Sales, M.F. 1993. Estudos taxonômicos de Mandevilla Lindl. subgênero Mandevilla (Apocynaceae) no Brasil. Tese de Doutorado. Universidade Estadual de Campinas, Campinas. 412p.

Sennblad, B. \& Bremer, B. 2002. Classification of Apocynaceae s.l. according to a new approach combining Linnaean and phylogenetic taxonomy. Systematic Biology 51: 389-409.

Simões, A.O.; Endress, M.E.; Niet, T. \& Kinoshita, L.S. 2006. Is Mandevilla (Apocynaceae, Mesechiteae) monophyletic? Evidence from five plastid DNA loci and morphology. Annals of the Missouri Botanical Garden 93: 565-591.

Simões, A.O. \& Kinoshita, L.S. 2002. The Apocynaceae $s$. str. of the Carrancas region, Brazil. Darwiniana. 40: 127-169.

Simões, A.O.; Kinoshita, L.S. \& Endress, M.E. 2007. New combinations in Mandevilla Lindley (Apocynaceae). Novon 17: 87-90.

Struwe, L.; Albert, V.A. \& Bremer, B. 1994. Cladistics and family level classification of the Gentianales. Cladistics 10: 175-206.

Thiers, B. [continuously updated]. Index Herbariorum: a global directory of public herbaria and associated staff. New York Botanical Garden's Virtual Herbarium. Disponível em $<$ http://sweetgum.nybg.org/ih/>.Acesso em 7 Nov 2011.

Woodson, R.E. 1951. Studies in the Apocynaceae. VIII. An Interim Revision of the Genus Aspidosperma Mart. \& Zucc. Annals of the Missouri Botanical Garden 38: 119-206. 